CHALLENGES IN ACCESSING HEALTH CARE SERVICES: CANADIAN CHILDREN

LIVING IN MIXED-STATUS FAMILIES

by

Rachel Ayla Caplan

Bachelor of Arts, Double Major in Psychology, and Kinesiology \& Health Sciences,

York University, 2008

\author{
A Major Research Paper \\ Presented to Ryerson University \\ in partial fulfillment of the \\ requirements for the degree of \\ Master of Arts \\ in the program of \\ Early Childhood Studies
}

Toronto, Ontario, Canada, 2011

(C) Rachel Ayla Caplan 2011

PROPERTY OF

APR -22011 enson University Library

PROPERTY OF

Ryerson University library 


\section{Author's Declaration}

I hereby declare that I am the sole author of this major research paper.

I authorize Ryerson University to lend this major research paper to other institutions or individuals for the purpose of scholarly research.

I further authorize Ryerson University to reproduce this major research paper by photocopying or by other means, in total or in part, at the request of other institutions or individuals for the purpose of scholarly research. 


\title{
CHALLENGES IN ACCESSING HEALTH CARE SERVICES: CANADIAN CHILDREN \\ LIVING IN MIXED-STATUS FAMILIES
}

(C) Rachel Ayla Caplan 2011

\author{
Master of Arts \\ Early Childhood Studies \\ Ryerson University
}

\begin{abstract}
Few studies have explored the prevalence of Canadian children with family members that have precarious legal status and the impact of parental immigration status on a child's access to health care in Canada. This quantitative research study uses a rights-based approach to discuss secondary data collected retrospectively between 2005-2009 at a medical clinic for uninsured patients in eastern Toronto, Ontario $(n=128)$. Demographic, immigration, and health-related factors are presented, and parental immigration status and health-seeking behaviours are explored. Findings indicate that: many Canadian children (Canadian-born and naturalized Canadians) are uninsured; Canadian children who attend the clinic are sick, as opposed to accessing well-child check-ups; and, a group of Canadian children living in mixed-status families are accessing health care facilities for medically uninsured patients. This study highlights mixed-status families, and the potential impact on children's access to health care. This study helps fill the research gap regarding uninsured Canadian children. It is intended to increase community and professional awareness about impingements made in fulfilling Canadian children's right to access the "universal" health care services they have been promised. In turn, this research could inform future policy, practice, and research within health care, educational, and governmental domains.
\end{abstract}

Key words: 'children's rights', 'social paediatrics', 'health-seeking behaviours' 


\section{Acknowledgements}

Mehru Ali: Thank you for your constructive feedback and support as my supervisor throughout this learning process.

Judith Bernhard: Thank you for helping initiate this important project and for your support and encouragement along the way.

Zoe Nugent: Thank you for the time and assistance you have provided, and especially for the use of your secondary data.

Niraj Mistry: Thank you for lending your knowledge, expertise, and resources throughout this project.

Lee Ford-Jones: Thank you for your invaluable feedback and for contributing as an active member on my Major Research Paper Committee.

Dragan Kljujic: Thank you for sharing your knowledge and skills in data analysis, in order to make this project possible.

Rachel Langford, and Angela Valeo: Thank you for your feedback and for asking the necessary questions to help improve this paper.

To my best friends, Mom \& Randi: Thanks for being there for me throughout this process, and more specifically, for your constructive feedback and suggestions.

To my wonderful fiancée, Rich: Thank you for being so supportive of all of my dreams and ambitions, and for just being you.

To my special family - Lori, Michael, Babbie, Zaida, Auntie Marcie, Uncle Barry, Bonnie, and Ted: Thank you for your unconditional love and support.

To my 'MRP Buddy', Caitlyn - The long hours of hard work at every coffee shop and library in the city have finally paid off? You have been my rock through this process.

Thank you to the wonderful Professors in the Early Childhood Studies program, who have challenged my thoughts, encouraged my growth as an academic, and motivated my intellectual development.

A special thanks to the caring and exceptional staff at the 'Clinic', for their dedication to fulfilling the rights of children.

I want to acknowledge all of the children who are currently living in Canada without health insurance and to assure them that we are fighting to fulfill their rights. 


\section{Dedication}

To three inspirational women in my life:

Dr. Judith Bernhard

$\&$

Dr. M. Lee Freedman

\&

Mom

"How wonderful it is that nobody need wait a single moment before starting to improve the world."

- Anne frank

Thank you for this invaluable lesson. 


\section{Table of Contents}

Chapter 1: Introduction

A Child's Right to Health Care in Canada .............................................................. 1

Ontario's Health Care System ........................................................................... 2

Canada's Immigrant Population .............................................................................. 3

Precarious Status and Access to Health Care ........................................................ 3

Barriers for Children Living in Mixed-Status Families ....................................... 4

Fulfilling a Child's Right to Health Care: The Clinic .............................................. 5

Purpose of this Study.............................................................................................. 5

Research Questions......................................................................................................... 6

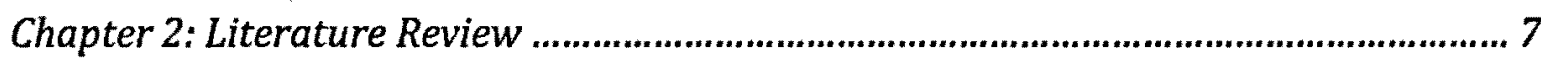

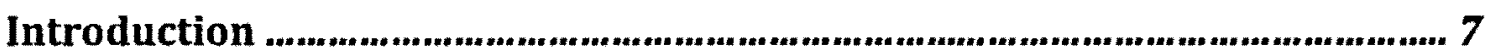

Theoretical Framework \& Scope of the Paper ............................................................ 8

Key Concepts and Terms ........................................................................................... 8

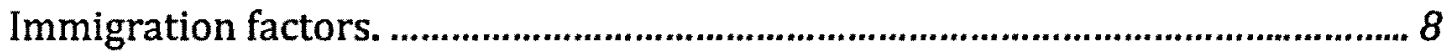

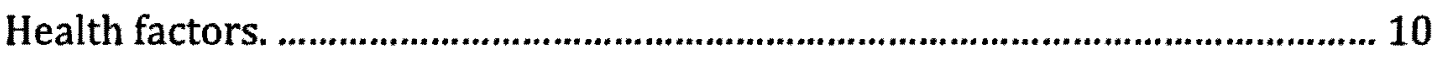

Children's Right to Health Care ........................................................................... 12

UN Convention on the Rights of the Child. ................................................... 12

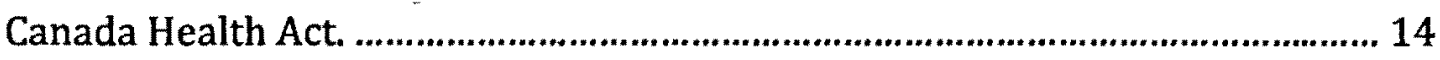

Canadian Charter of Rights and Freedoms. ......................................................... 15

Violations of Children's Right to Health Care in Canada ............................... 15

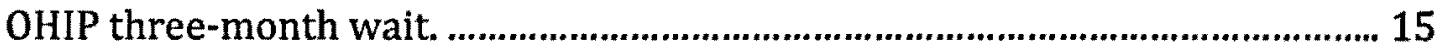

Canadian children living in mixed-status families. ........................................... 17

Social Paediatrics; A Chilling Impact on Child Health and Development ..... 20

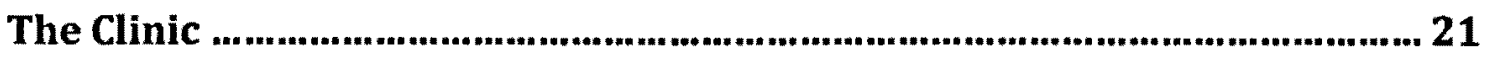

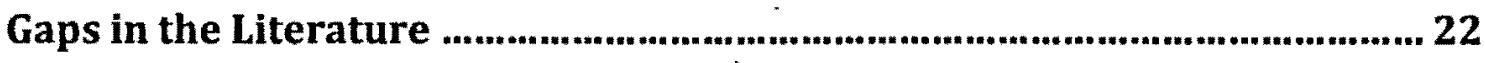

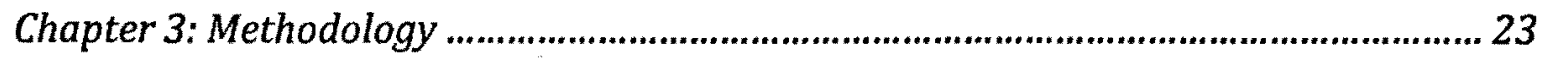

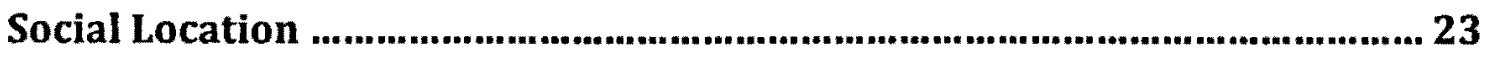

Rationale for a Quantitative Design ................................................................. 23

Key Concepts Revisited and Variable Modification .......................................... 25 


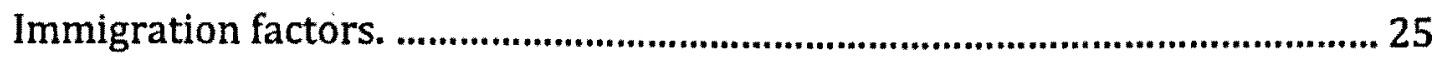

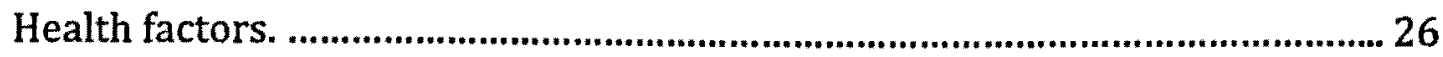

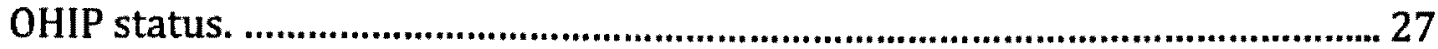

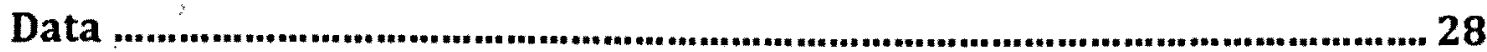

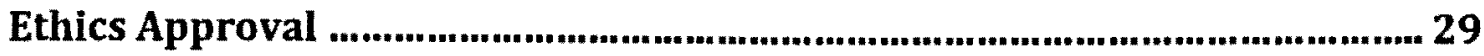

Research Design and Data Collection Process ................................................. 29

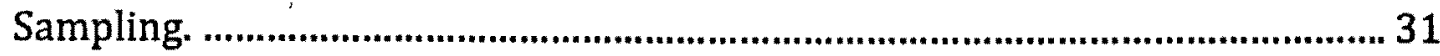

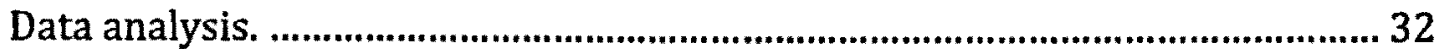

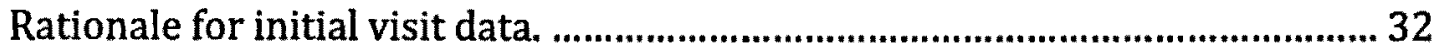

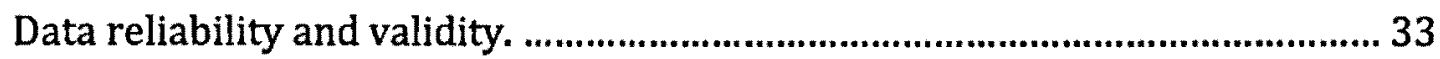

Organization of Chapter 4: Results Section ....................................................... 33

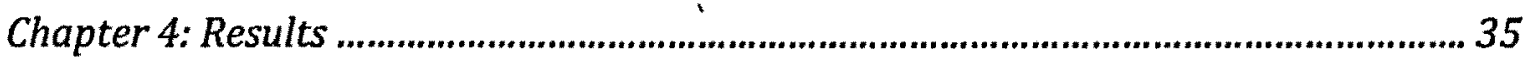

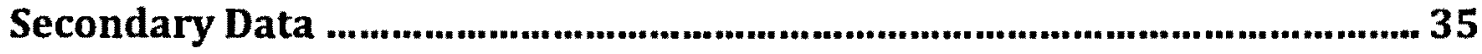

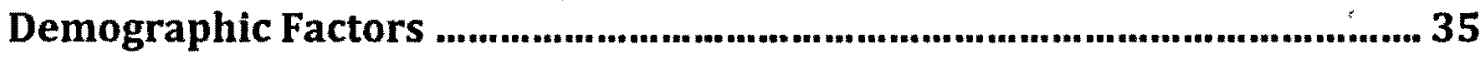

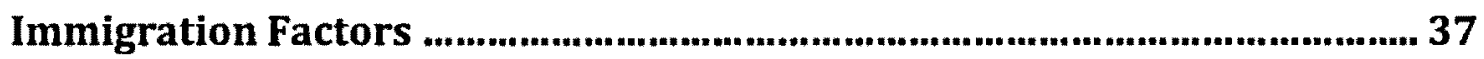

Child's region of origin and principal language spoken. ..................................... 37

Length of time in Canada and living arrangements. ............................................. 37

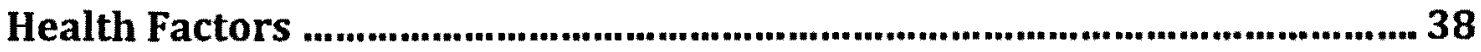

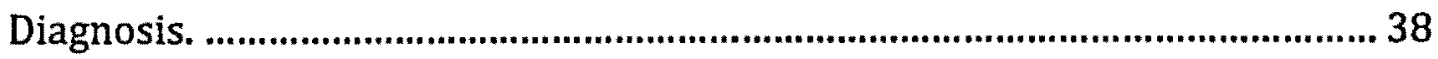

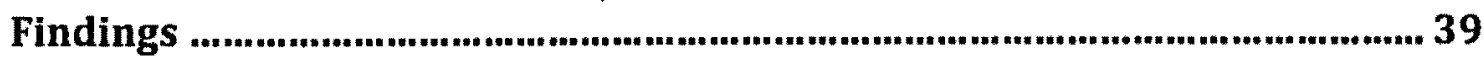

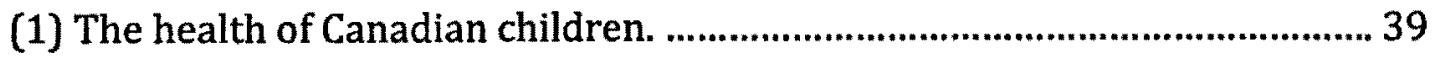

(2) OHIP status of Canadian children living in Ontario. ..................................... 39

(3) Canadian-born and naturalized Canadian children in Canada. ....................40

(4) Canadian children in mixed-status families. .................................................... 41

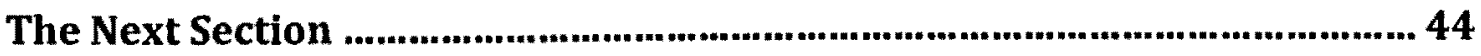

Chapter 5: Discussion and Conclusion .......................................................................... 45

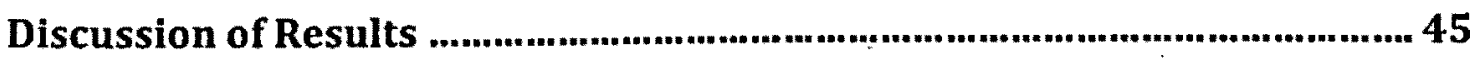

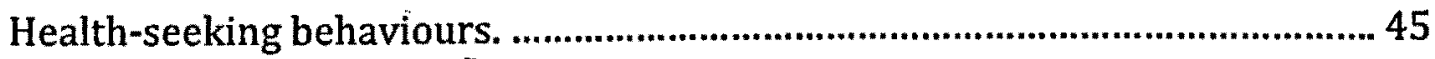

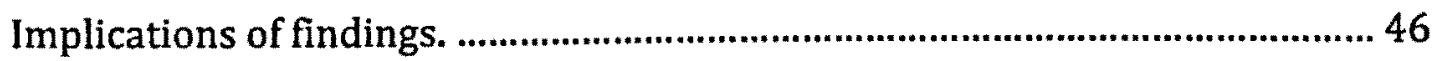

(1)The health of Canadian children. .................................................4 46

(2) OHIP status of Canadian children living in Ontario. ........................47 
(3) Canadian-born and naturalized Canadian children in Canada. ...... 48

(4) Canadian children in mixed-status families. ....................................48

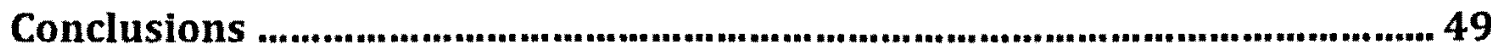

Future directions and recommendations in policy, practice, \& research. ........ 49

Role of paediatricians. ................................................................................. 49

Modifications to OHIP eligibility. ..........................................................5 50

Immigration research. ........................................................................ 51

Future directions and recommendations in the community. .......................... 52

Knowledge of children's rights and advocacy. ..................................... 52

Collaboration. .................................................................................................. 53

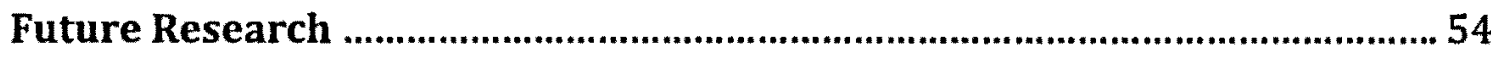

Contribution of this Study \& Value to Early Childhood Education ................54

Closing Statement: A Child's Right to Health Care .........................................56

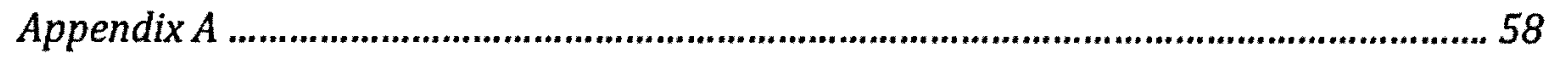

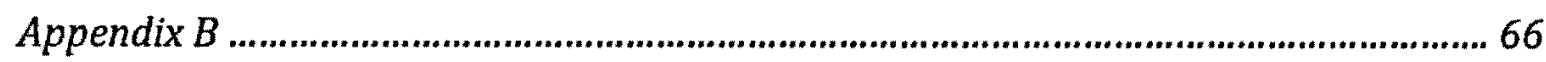

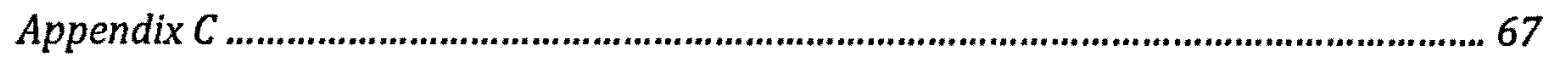

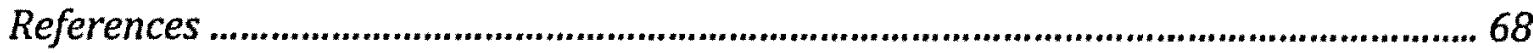




\section{Chapter 1: Introduction}

\section{A Child's Right to Health Care in Canada}

Canada is recognized for its universal and comprehensive health care system (Iglehart, 1986; Canadian Council on Social Development [CCSD], 2008). In 1984, the Canada Health Act was created to emphasize Canadian values of universality, portability, and accessibility of health care services for all Canadian citizens, and states that, "the primary objective of Canadian health care policy is to protect, promote and restore the physical and mental well-being of residents of Canada and to facilitate reasonable access to health services without financial or other barriers" (Department of Justice Canada [D]C], 1985).

Canada's international agreements illustrate its commitment to health care services for all people living in the country. For example, article 23 of the United Nations Convention on Refugees (UNCR), ratified by the Canadian government, states that refugees are entitled to the same social and medical assistance that its citizens have [United Nations High Commissioner for Refugees [UNHCR], 1951). Furthermore, in November 1989, Canada ratified the Charter of the United Nations Convention on the Rights of the Child (UNCRC), which commits state parties to:

"...recognize the right of the child to the enjoyment of the highest attainable standard of health and to facilities for the treatment of illness and rehabilitation of health. State Parties shall strive to ensure that no child is deprived of his or her right of access to such health care services" (UN, 1989/1991, Article 24).

The Canadian Charter of Rights and Freedoms of 1982 guarantees equal rights to all citizens and non-citizens in Canada (DJC, 1982). Nevertheless, in Canada, and more 
specifically, in Ontario, many medically uninsured immigrants, refugees, asylum seekers, and even Canadian children living in mixed-status families, are recurrently denied access to health care services (Bernhard et al., 2007).

\section{Ontario's Health Care System}

In order to access health care services in Ontario, one may either pay out-of-pocket or possess a health card issued by the Ontario Ministry of Health and Long-Term Care, which indicates coverage under the Ontario Health Insurance Plan (OHIP). To qualify for OHIP, a person must be a Canadian citizen or permanent resident. However, OHIP coverage does not become effective until three months following the establishment of residency by new immigrants.

Other groups that experience the three-month "waiting period" are temporary residents, Canadian-born citizens of provinces other than Ontario, and Canadian-born citizens who leave the country for an extended period of time and return to Ontario thereafter. During this "waiting period", the Ontario ministry advises residents to purchase private health insurance, in case they become ill during this time. Only a few groups are exempt from the waiting period, such as newborn babies in Ontario. However, if a baby is born in Ontario, but not within an Ontario birthing hospital, or at home while attended by an Ontario registered midwife, the child's parents must visit a governmental office to provide the child's proof of Canadian citizenship, and parental proof of identity and residency in Ontario in order to obtain their newborn's health card. Furthermore, OHIP health cards expire every two to seven years, and therefore must be renewed. Parents or 
guardians of children under the age of 15 and-a-half years of age must visit a governmental office and provide proof of identity and residency in Ontario to obtain their health cards (Ontario Ministry of Health and Long-Term Care [OMHLC], 2008).

\section{Canada's Immigrant Population}

About 250,000 immigrants arrive in Canada each year as skilled workers, entrepreneurs, investors and their families, or as refugees. In addition, about 130,000 people come as students and 150,000 as temporary workers, and many of them choose to stay on in Canada (Bernhard \& Young, 2009; Citizenship and Immigration Canada, 2011). While no reliable figures are available, it is estimated that 40,000 to 600,000 men, women, and children are living in the country without permanent legal status (Bernhard \& Young, 2009). For the purposes of this paper, this population is referred to as living with no status or living with precarious status, and consists of those who came to Canada as visitors, students, temporary workers, or refugee claimants, who are undocumented, unauthorized, or waiting to establish their legal status (Bernhard \& Young, 2009).

\section{Precarious Status and Access to Health Care}

According to Goldring et al. (2009), those with precarious status in Canada forfeit the fundamental entitlements provided to permanent residents and citizens of Canada. They are not covered by provincial health insurance policies and therefore do not have access to the regular health care system. A majority of health and service providers require proof of identification in order to assess citizenship status, and therefore, entitlement to health care (Goldring et al., 2009). Although a 
few community-based programs have been set up in some cities, they are poorly funded and not well-known. In addition, many people with precarious or no status fear being reported to Citizenship and Immigration Canada, which may result in deportation to their home country (Bernhard et al., 2007; Goldring et al., 2009).

\section{Barriers for Children Living in Mixed-Status Families}

Precarious parental immigration status has been shown to negatively impact on children's access to health care services, even if they are Canadian-born and therefore, Canadian citizens (Sigona, 2011). For the purposes of this paper mixed-status refers to families consisting of members who have differing citizenship status within Canada. For example, one parent is undocumented while their child is Canadian-born. Bernhard et al. (2007) report that parents' status has been used to justify denying children's rights to health care. They go on to explain that parents are often afraid to register their children for health care services, out of fear of deportation, as Canadian-born children have been deported with their parents of precarious status in the past. Furthermore, money is a substantial barrier for Canadian children's access to health care, as their undocumented parents cannot afford to pay out-of-pocket (Bramham, March 11, 2011). Although these uninsured children are Canadian citizens, they appear to face barriers similar to their undocumented, uninsured parents. For example, Caulford and Vali (2006) delineate barriers for uninsured patients, such as being turned away from health clinics due to rigorous enrollment requirements or maximum capacity restrictions, as well as

denied care at emergency departments due to inability to pay for treatment. 


\section{Fulfilling a Child's Right to Health Care: The Clinic}

In 2000, a Family Health Team from a hospital in eastern Toronto opened a health care facility to provide free, high quality, comprehensive, and accessible health care services for uninsured Canadian citizens and non-citizens (Caulford \& Vali, 2006). Located in eastern Toronto, Ontario, Canada, this clinic serves uninsured children and families with varying immigration statuses, such as Canadian citizens, landed immigrants, refugees, temporary residents, and undocumented individuals. Dr. Zoe Nugent led a research team from the Hospital for Sick Children (HSC), who gathered primary data from the Clinic for the years of 2005 until 2009, and found that approximately 128 Canadian children attended this clinic for the first time; 75 percent of them being Canadian-born and 25 percent being naturalized Canadians (acquired citizenship). Of the 128 Canadian children, 32 percent had expired OHIP; 19.5 percent had OHIP; 18 percent were returning Canadians in the three-month waiting period; 6.3 percent had lost OHIP cards; 4.7 percent had applied for OHIP;

3.9 percent were landed immigrants in the three-month waiting period; 1.6 percent were ineligible; and 14 percent had no explanation recorded (Nugent, 2009). For the purposes of this paper, the clinic located in eastern Toronto will be referred to as the "Clinic".

\section{Purpose of this Study}

Through the use of secondary data (originally collected by researchers at the HSC), this study will examine the demographic, immigration, and health-related 
factors of the 128 Canadian children who begun attending the Clinic between 2005-2009.

While this study might not directly change health care or immigration policy and practice within Canada, it will contribute to the knowledge base on migration status and health-seeking behaviours of families who use community-based clinics for their children's health care. It will focus particularly on mixed-status families, raising questions about the implementation of the Canada Health Act and Canada's commitment to international conventions.

\section{Research Questions}

(1) What do the data show about the health of Canadian children at the Clinic?

(2) What are the key demographic characteristics of families who use the Clinic?

(3) What is the health insurance status of children who use the Clinic?

(4) Are Canadian children's rights to health care ensured by current institutional policies and provisions?

The following section will look at the literature pertaining to these questions. 


\section{Chapter 2: Literature Review}

\section{Introduction}

Few studies have explored the prevalence of Canadian children with parents who have precarious legal status and the impact of parental immigration status on one's child's access to health care in Canada (Bernhard et al., 2007; Caulford \& Vali, 2006). Simich et al. (2007) claim that: "Variations in immigration status, or lack thereof, determine degree of access to health care and benefits" (p. 369). Ruiz-Casares et al. (2010) argue that even if children are Canadian and eligible for health coverage, their parents' fear of the consequences that seeking health care might have on their own immigration status prevents them from obtaining necessary documentation for their children.

In accordance with the legal obligation of the State to comply with the United Nations Convention on the Rights of the Child (UNCRC), the Canada Health Act (CHA), and the Canadian Charter of Rights and Freedoms (CCRF), it is clear that children's right to health care is being violated in Canada for children of parents with precarious legal status. Violating a child's right to health care negates all three principle rights of children to protection, participation, and provision, and all four of the guiding principles of the UNCRC that ensure the child's right to non-discrimination, best interest, life, survival, and development, and respect for their views. Violating a child's right to health care further violates the CHA and the CCRF. 


\section{Theoretical Framework \& Scope of the Paper}

This paper is informed by a rights-based approach to explore the violation of children's right to health care within the Canadian province of Ontario. Synonymous with the author's orientation towards problematizing social justice issues, the intent is to advocate for the rights of all children, regardless of their parent's status within Canadian society. The scope of this paper is limited within a Canadian context, particularly within Ontario, due to the specific nature of Ontario's health care system, as well as the large population of migrants living within Ontario, Canada.

\section{Key Concepts and Terms}

\section{Immigration factors.}

A mixed-status family is classified as a family consisting of members with differing citizenship status within Canada. These may include members who are: Canadian citizens by birth or through naturalization; landed immigrants; refugees; temporary residents or workers; and "undocumented".

Naturalized Canadians are people who have acquired their citizenship or nationality as Canadian citizens (CIC, 2011). They are legally entitled to access health care services through OHIP. Landed immigrants are defined by the Ontario Medical Association (OMA) as those who have "moved to Canada for the first time and who are not refugees or permanent residents, but who are in the country legally, with the full sanction of the federal government" (OMA Policy Report, 2011, p.14). They are subject to the three-month waiting period prior to qualifying for OHIP in Ontario. Refugees are those in need of protection out of fear of persecution, 
torture, or cruel and unusual punishment upon returning to their home country (CIC, 2011). In Canada, refugees have limited rights to health care (Goldring et al., 2009). Temporary residents visit Canada and live there temporarily as tourists, to visit friends or family, for business trips, for humanitarian purposes, or as foreign workers or students (CIC, 2011; Goldring et al., 2009). Temporary workers, including seasonal workers, foreign workers, construction workers, and caregivers, have legal status to live and work in Canada, but do not have permanent residency in the country. Therefore, they must wait the three-month period prior to obtaining OHIP coverage [Goldring et al., 2009).

A variety of definitions exist to explain those who are "undocumented". For the purpose of this paper, Goldring et al.'s (2009) definition will be used. They define undocumented people as: "people who cross borders without authorization, or who reside or work without the presumed 'full' legal status of citizenship or the 'nearly full' status of permanent residence" or "are known to the state but no longer have lawful status" (p.239). They may also include those who have applied for refugee status or temporary residents or workers who choose to stay in country after a final negative decision for citizenship or residency, or after a visa has expired. Therefore, they do not have a recognized migratory status, and while they can access emergency hospital services, they must pay out-of-pocket for them. Canadian agencies that receive provincial or federal funding are not allowed to serve patients with precarious or undocumented status (Goldring et al., 2009). 


\section{Health factors.}

According to the World Health Organization (2010), health is defined as "a state of complete physical, mental and social well-being and not merely the absence of disease or infirmity" (p.116). Access to services, such as health care services largely impact on people's health and well-being (Goldring et al., 2009). Access to prenatal care during pregnancy and postnatal care after birth, as well as well-child check-ups and administration of childhood immunizations to prevent infectious diseases are essential to healthy child development, and improved health of the community overall (Goldman \& Pebley, 1994; Chabot et al., 2004).

There is a substantial quantity of literature discussing the importance of prenatal care in reducing adverse health outcomes for mothers and children through medical, nutritional, and educational interventions. For example, prenatal care has been used to identify at-risk mothers who have a higher chance of premature delivery or are carrying a child that is underweight. (Goldman \& Pebley, 1994; Alexander \& Korenbrot, 1995; and others).

Childhood immunizations are used to prevent, eliminate, or reduce common childhood infectious diseases, and are an ideal way to sustain optimal health (Chabot et al., 2004). By 2005, all provinces in Canada had begun universal infant immunization programs. Through the Canadian Immunization Monitoring Program, Bettinger et al. (2010) carried out a study conducting active surveillance for invasive pneumonococcal disease in children enrolled in immunization programs across Canada between 2000-2007. They found that immunization programs had substantially decreased the prevalence of invasive pneumonococcal disease in North 
American children. Specifically, prior to $2006,250-300$ cases of pneumonococcal disease were found in children enrolled in the study, while only 90-120 cases were found after the introduction of the immunization program in 2006. Furthermore, prior to 2006, the childhood mortality rate for children with pneumonococcal disease was 5-6 annual deaths, but following program introduction in 2006, the rate was 0-1 death. Interestingly, indirect effects were also seen in older, unimmunized children.

Immunizations are beneficial for individual children, but they are additionally valuable to the general community for two main reasons. Firstly, vaccinating young children has been consistently shown to directly benefit their health and well-being through infectious disease prevention. In addition, immunizations benefit the health and well-being of community members. For example, since children contribute significantly to the spread of the flu, immunizing children against the flu disrupts its transmission to others within the community (Child Health Alert, 2010). Chabot et al. (2004) say that:

The societal approach is particularly appropriate for immunization programs, which are principally supported by government and which accrue benefits not only to those who are vaccinated but also to those who are not, due to reduced likelihood of exposure (p.1993).

Secondly, immunization programs have reliably proven to be cost-effective to society and amongst the most optimal investments in health, since: "For most childhood vaccination programs, however, every dollar invested leads to significant savings to the society" (Chabot et al., 2004, p.2022). Therefore, the Canadian 
National Advisory Committee for Immunization recommends routine immunization of infants for common childhood diseases, such as hepatitis B, meningococcal disease, pneumonococcal disease, varicella, and others (Chabot et al., 2004).

\section{Children's Right to Health Care}

Waterston and Goldhagen (2006) discuss the interactions between social, economic, and physical factors that impact the health and well-being of children. They state that: "It is only through the fulfillment of children's rights that equity in child health can be achieved" (p.176).

To understand the importance of fulfilling children's right to health care, one must recognize the interconnected nature of children's rights. Lansdown (2000) emphasizes the importance of appreciating the interrelation between all rights in the UNCRC in order to promote respect for children's right to health services. Children's rights are also inalienable, or irrevocable in that they cannot be taken away. Furthermore, children's rights are interdependent in that denial of one right result in denial of other rights (Raman et al., 2007). Various national and international treaties and acts have been ratified by Canada in order to ensure the rights of all children. Those that will be discussed in this paper include the: UNCRC; Canada Health Act; and Canadian Charter of Rights and Freedoms.

\section{UN Convention on the Rights of the Child.}

The UNCRC was adopted by the General Assembly of the United Nations in 1989, and ratified by Canada in 1991 (Ruiz-Casares, 2010). Snow (2009) refers to the three types of children's rights as reflected in the UNCRC; civil and political 
rights, that are known as participatory rights; economic, social, and cultural rights, that are known as protection rights, and provision rights. Furthermore, the UNCRC is framed by four guiding principles, which emphasize children's right to non-discrimination, best interest, life, survival, and development, and respect for their views.

Article 24 of the UNCRC indicates that the State must: "recognize the right of the child to the enjoyment of the highest attainable standard of health and to facilities for the treatment of illness and rehabilitation of health. State Parties shall strive to ensure that no child is deprived of his or her right of access to such health care services" and to "ensure appropriate prenatal and postnatal health care for mothers" (UNCRC, 1989/1991).

Violating children's right to health care violates all three types of rights represented in the UNCRC. Provision rights entail children's right to survive and develop by all available environmental and resourceful means. Protection rights entail safeguarding children from risks to their mental, physical, and emotional well-being. Participation rights involve the empowerment and capacity of children's involvement in decision-making and acting in issues that affect them (Kurtz et al., 1994).

Violating children's right to health care also violates all four guiding principles represented in the UNCRC. Article 2 of the UNCRC applies to children's right to non-discrimination, "irrespective of the child's or his or her parent's or legal guardian's race, colour...or other status" (UNCRC, 1989/1991). Yet, in the case of 
Canadian children with parents that have precarious status, access to health care is denied based on their parent's immigration status.

Article 3 of the UNCRC guarantees the best interest of the child to be of primary consideration when making decisions regarding the child (UNCRC, 1989/1991). Freeman (2007) argues that to fully support a child and his or her best interest, support for his or her caregiver and the caregiver's decisions are necessary as well. Preventing access to health care services for this group of children denies the children's right to their best interest, as well as denying their right to life, survival, and development (article 6); another guiding principle of the UNCRC.

Article 12 of the UNCRC refers to children's right to have their views respected (UNCRC, 1989/1991). Since children living with parents of precarious status are systematically excluded from the Canadian health care system, their voices and data are also excluded from health care research and national health reports. Furthermore, these groups of children may not only have their views and opinions disrespected, but they haven't even been given a chance to have their voices heard.

\section{Canada Health Act.}

The Canada Health Act (CHA) was passed in 1984 by the Government of Canada, with the aim to "ensure that all eligible residents of Canada have reasonable access to insured health services on a prepaid basis, without direct charges at the point of service for such services". Furthermore, the primary objective of the act was set out "to protect, promote and restore the physical and mental well-being of 
residents of Canada and to facilitate reasonable access to health services without financial or other barriers" (Health Canada, 2009).

\section{Canadian Charter of Rights and Freedoms.}

In part 1 of the Canadian Charter of Rights and Freedoms (CCRF), article 15.1 guarantees equality rights to all individuals living in Canada, without any type of discrimination. The Charter specifically states that:

"Every individual is equal before and under the law and has the right to the equal protection and equal benefit of the law without discrimination and, in particular, without discrimination based on race, national or ethnic origin, colour, religion, sex, age or mental or physical disàbility" (DJC, 1982).

\section{Violations of Children's Right to Health Care in Canada}

\section{OHIP three-month wait.}

The Ontario Medical Association (OMA) published a comprehensive paper in April of 2011, detailing the three-month wait period to qualify for OHIP coverage for legal immigrants and returning Canadian citizens. The Ontario government implemented this wait period in 1994 as a cost-saving strategy. The wait applies to new legal immigrants, as well as Canadians returning to Ontario after living outside the province for more than $\mathbf{2 1 2}$ days in a year. The three-month wait period has been identified as having multiple negative consequences, including: delayed health care; financial burden; and lack of management of chronic illness (OMA, 2011).

Delayed medical care has been associated with compromised health and negative long-term health effects (Ruiz-Casares et al., 2010; Weissman et al., 1991). 
Delayed care also results in higher medical costs than if preventative and immediate medical care were provided (Roos et al., 1999). Furthermore, delayed care results in increased exposure of unwell individuals to otherwise healthy members of society, resulting in the spread of infectious diseases.

The Ontario government encourages those subject to the three-month wait period to purchase private health insurance (Health Canada, 2009). Yet, private insurance is often inaccessible, insufficient, unclear, or denied (OMA, 2011). Furthermore, private insurance requires out-of-pocket payments, and for those that cannot afford to pay for private insurance, if they or a family member become ill or require medical attention during the three-month wait, they are forced to forego treatment.

According to the 2011 OMA report, many physicians reported treating patients that had chronic illnesses in the emergency department. Patients often reported that they had not received regular medical care to treat their chronic condition due to lack of access to appropriate health care services. As a result patients end up in the emergency departments for issues that could be dealt with through preventative and maintenance medical services.

The Ontario government defends the three-month wait by iterating measures that they have put in place to ensure the health and well-being of those subject to the three-month wait. One claim involves the existence of Community Health Centres that provide health care access free of charge for immigrants during the wait. However, the wait lists are incredibly long, creating a barrier to access treatment at these centres. It is also claimed that midwifery services are provided 
for pregnant women during the wait. However, prenatal and postnatal tests and follow-up appointments are not necessarily provided. While those who have suffered severe injuries due to an accident are provided free emergency care in the hospital, tests and follow-up appointments are not offered, unless paid for out-ofpocket.

The most disconcerting part of this regulation is that except for newborn babies, OHIP-eligible adopted children under 16 years of age, protected persons, and those moving to long-term care facilities in Ontario, children are not exempt from this three-month wait period. Thus, the OHIP three-month wait is in clear violation of the UNCRC, the Canada Health Act, and the Canadian Charter of Rights and Freedoms. During the three-month wait, immigrant and returning Canadian children being deprived of their right to access health care services, which is completely contradictory to article 24.1 of the UNCRC. During the three-month wait, immigrant and returning Canadian children do not have access to insured health services, as guaranteed in the Canada Health Act. Thus, immigrant and returning Canadian children have their equality rights violated, as they are discriminated against based on their immigration status, which is contradictory to the Canadian Charter of Rights and Freedoms.

\section{Canadian children living in mixed-status families.}

Canada accepts migrants for economic, family, and humanitarian reasons, but assigns precarious legal status to many other immigrants (Goldring et al., 2009). According to Bernhard and Young (2009): "few people realize how many residents - 
including families with young children - live permanently in Canada with varying gradations of legal status." Furthermore, Bernhard et al. (2008) demonstrate that families with mixed legal statuses face vulnerabilities that lead to negative social and health outcomes, even if the children are Canadian citizens. Unfortunately, as Bernhard et al. (2007) have identified, Canadian children living in families with precarious status tend to acquire their parents' precarious status, as opposed to acquiring their status as Canadian citizens. Therefore, providing timely access to health care to medically uninsured immigrants and refugees is an important factor contributing to the well-being of children in mixed-status families (Caulford \& Vali, 2006). Some of the issues in the literature concerning Canadian children in mixed-status families involve children prior to birth, as well as after birth.

Bernhard and Young (2009) discuss the many pregnant women who have precarious status in Canada, but are afraid to access medical care or even to obtain birth registration for their children out of fear of having their child apprehended. Furthermore, since the federal and provincial government limit health care access to Canadian citizens and permanent residents, many pregnant women are turned away from health care clinics, even though their unborn child's health may be at stake. In a study by Bernhard et al. (2007), a participant revealed being turned away from a health clinic in Toronto when she was pregnant. She said:

They said to me, "You know what? You don't have full status. We are booked with non-status women." And I was pregnant, sick, nauseated, depressed - everything. And they told me, "You don't have status. You need to find another clinic. We don't have space." (p.106). 
The right of children to have appropriate prenatal and postnatal care, as stated in article 24.2 in the UNCRC is clearly violated in this case. In addition, the Charter of Rights and Freedoms is violated by the fact that pregnant women without status are being discriminated against, in turn preventing access to health care for their unborn child.

Parents with precarious status are unable to obtain social insurance numbers, and therefore cannot work legally in the country. They are ineligible to receive Canada Child Tax Benefits to help support Canadian children less than eighteen years of age (Bernhard et al., 2007). They cannot access health care for themselves or childcare for their children (Bernhard \& Young, 2009). In 2007, Bernhard et al. conducted a mixed-method pilot study looking at the effects that living in Toronto, Canada with precarious legal status had on the well-being of their children and families. They found that precarious parental status was consistently used to deny children of their rights, even if the children were Canadian-born. Ali (2008) found that immigrant parents were concerned about their limited ability to provide appropriate health care for their children. In her study, many parents stated their lack of financial resources to ensure adequate health care for their children. In addition, Bramham (March 11, 2011) reported that the main barrier for Canadian children in mixed-status families in accessing health care is money, as their undocumented mothers, (who have often been abused and left destitute by their husbands that were sponsoring them), cannot afford to pay out-of-pocket for their child's medical care. Unfortunately for these children, evidence has shown that as 
family income decreases from the highest socioeconomic status, children's health burden increases (Ford-Jones, 2008).

\section{Social Paediatrics; A Chilling Impact on Child Health and Development}

Ford-Jones et al. (2008) present a definition of social paediatrics, as defined by the European Society of Social Paediatrics and Child Health (ESSOP) as:

A global, holistic, and multidisciplinary approach to child health; it considers the health of the child within the context of their society, environment, school, and family, integrating the physical, mental, and social dimensions of child health and development as well as care, prevention and promotion of health and quality of life.

Guyda et al. (2006) emphasize the importance of social paediatrics in caring for the most vulnerable populations, such as those experiencing social exclusion (e.g: children living in mixed status families). The field of paediatrics has produced ample evidence in the past decade, which includes the importance of prenatal and early childhood experiences in healthy child development (Ford-Jones, 2008).

The necessity of quality prenatal care and early childhood health care is underscored in the social paediatric literature. At the 2004 ESSOP conference, the main message to health care providers was to incorporate "best practices in early childhood prevention as a pivotal piece in the promotion of better health and a better future for all children of the world" (Guyda et al., 2006, p.644). Ramey et al. (1998) provide empirical evidence in favor of early childhood health care and Case et al. (2005) discuss the cognitive, academic, and social improvements made through the implementation of high-quality early childhood health interventions. Case et al. (2005) also suggest that prenatal and early childhood health and 
circumstances impact one's health in early adulthood. Ford-Jones et al. (2008) summarize some of the neurological milestones that are achieved during prenatal and early childhood development. For example, during the first few years of life, architectural structuring and hardwiring of the brain occurs, along with development of vision, emotional control, habitual response mechanisms, and language. During the preschool years, skills such as socialization and cognitive functioning develop further. Unfortunately, for children waiting the three-month period prior to obtaining OHIP coverage, as well as for Canadian children in. mixed-status families, lack of access to adequate health care may result in insufficient prenatal and early childhood care necessary for optimal child development.

\section{The Clinic}

A group of health care workers who believe in fulfilling every child's right to health care, regardless of their family's circumstance or immigration status volunteer their time and expertise at the Clinic. Their purpose is to provide free, high-quality, comprehensive, and accessible health care services for uninsured Canadian citizens and non-citizens alike. Since its inception in 2000, the Clinic has served uninsured children and families with varying immigration status, such as Canadian citizens, landed immigrants, refugees, temporary residents, and undocumented individuals. Due to its heterogeneous population with respect to immigration status and therefore OHIP coverage, data collected from this unique clinic is invaluable to the study of children living in mixed-status families. 


\section{Gaps in the Literature}

A fundamental limitation of this literature review is that few studies have assessed the challenges in accessing health care for those living with precarious legal status, and even less research has examined the effects of parents' status on Canadian children living in these mixed-status families (Bernhard \& Young, 2009). This gap in academic literature may, in part, be due to the comparatively small and relatively misunderstood group of people living with precarious status within Canadian society (Goldring et al., 2009). Furthermore, the seemingly insurmountable barriers set up by institutional ethics committees, who are legally obliged to abide by federal guidelines, prevent the development of research in this field. For example, Bernhard and Young (2009) discuss the barriers they faced while trying to conduct research with a population of undocumented individuals. They recognized that if subpoenaed to court, they would be forced to release information to Citizenship and Immigration Canada, putting their potential participants at risk of deportation or separation from their children. Refusing to put their participants at risk, Bernhard et al. were only able to conduct single interviews on each participant, in order to avoid documenting their identifiable information.

Another restrictive aspect of this research domain is the lack of quantitative studies pertaining to the topic. Since quantitative research is a valuable mechanism for encouraging policy implementation and change, they are important to undertake. The next section of this paper details information about the quantitative methodology used in this study, with the prospect of initiating a path for future quantitative research in this understudied field. 


\section{Chapter 3: Methodology}

\section{Social Location}

As an educated third-generation Canadian, Caucasian, heterosexual Master of Arts student at Ryerson University, I have never conscientiously suffered marginalization due to my nationality, race, sexuality, or level of education, and therefore recognize my place of power and privilege within Western society. However, being female, Jewish and of Israeli-descent, as well as having lived in a single-parent family for six years, and in a blended family for over ten years, I have personally (and historically) experiencèd marginalization due to my gender, religion, culture, and family circumstance. As a child, I quickly learned that in order to have my rights fulfilled, I needed to be my own advocate. Refusing to end with myself, I continue to advocate for children and work with them in their learning to liberate themselves from oppression and systemic discrimination. Therefore, as a child advocate and avid believer in fulfilling the rights of all children, in combination with discovering the existence of data showing a group of children lacking access to health care, I knew that I had to take scholarly action.

\section{Rationale for a Quantitative Design}

A quantitative research design was most appropriate for this type of research. Measuring one's observations is a fundamental component of data collection, and utilizing numbers to describe these observations is referred to as the quantitative approach (Gravetter \& Wallnau, 2007). More specifically, descriptive statistical techniques were used in this study due to the limited sample size 
( $n=128)$. According to Gravetter and Wallnau (2007), descriptive statistics summarize, organize, and simplify data. The specific descriptive statistical technique used was frequency distribution. Frequency distribution is "an organized tabulation of the number of individuals located in each category on the scale of measurement" (Gravetter \& Wallnau, 2007, p. 37). A quantitative approach was chosen based on the specificity of the research questions, and based on the secondary data that was available at the time of study initiation.

Recall the original HSC findings that 128 Canadian children that attended the Clinic had varying OHIP statuses (Nugent, 2009). These data as well as the literature pertaining to children living in mixed-status families (as discussed in Chapter 2, of this paper) incited the initiative to find out if children's OHIP status is related to parental immigration status. However, due to a very limited amount of documentation regarding parental information of children that attended the Clinic, quantitative analyses could not be done using the variables of child's OHIP status and parent's immigration status. Yet, twelve children did have parental or family-member immigration status available. Through primary data collection, additional data was compiled with the secondary data collected by the HSC researchers. Descriptive information pertaining to this sub-group of the 128 children can be found in Figure 12, in Chapter 4 of this paper.

Unable to execute the original plan, the researcher decided to explore the Canadian childrens' Ontario health coverage, parental health-seeking behaviors, parental immigration status, and other immigration and health-related variables from the secondary data. Immigration status of these children was controlled for, 
since all of the children were Canadian (either born in Canada or naturalized Canadians). The immigration factors examined were comprised of the: child's principal language, living arrangement, length of time in Canada, and country of origin; and the health-related factors included: diagnosis and well-child check-up. The OHIP status for each child was documented and was either: lost health card; have current health card; expired health card; applied for OHIP; ineligible for OHIP; landed immigrant status in the three-month waiting period; returning Canadian in the three-month waiting period; or either no explanation was documented or another explanation was recorded (Nugent, 2009).

\section{Key Concepts Revisited and Variable Modification}

\section{Immigration factors.}

For the purposes of this paper, mixed-status families consist of members with differing citizenship status within Canada and may include members who are: Canadian citizens by birth or through naturalization; landed immigrants; refugees; temporary residents or workers; and undocumented individuals. Some of the immigration factors explored in this study include child's country of origin, principal language, length of time in Canada, and living arrangement (Nugent, 2009). However, modification of some immigration factor categories was necessary in order to present and analyze the data. For example, some of the factors were collapsed into larger categories.

In the original HSC research, "country of origin" was recorded as 21 categories, including: Albania, Arab Emirates, Bangladesh, China, Cuba, Egypt, 
Guyana, Hong Kong, India, Iran, Jordan, Kazakhstan, Kuwait, Martinique, Nigeria, Pakistan, St. Vincent, St. Lucia, Thailand, United States of America (U.S.A), and Canada (Nugent, 2009). However, for this study, the categories were collapsed into two categories that included: "Canada/U.S.A" and "other countries", since this study focused on Canadian children in particular. It is important to note that while the immigration status of all children in the study is "Canadian", 75 percent were born in Canada and 25 percent were naturalized Canadians, and therefore, may not have a "country of origin" as Canada.

In the original HSC research and for this study, "child's principal language" was recorded and analyzed in 12 categories, including: Spanish, Slavic languages, Arabic, Bengali, Gujrati, Farsi, Urdu, Korean, Chinese, Tagalog, English, and French (Nugent, 2009). The "living arrangement" of the children analyzed in this study utilized the same four categories as those recorded in the original HSC study. They include: apartment, house, shelter, or shared living circumstances (Nugent, 2009). The categories describing the child's "length of time in Canada" remained the same as well, and includes: less than three months, six to twelve months, two to five years, more than five years, and always (Nugent, 2009).

\section{Health factors.}

For the purposes of this paper, health-related factors analyzed in this study included: diagnosis, and well-child check-up for when the child first attended the Clinic (Nugent, 2009). However, similar to the immigration factors, modification of 
some health-related categories was necessary to present and analyze the data. Some of the factors were collapsed into larger categories.

In the original HSC research, "diagnosis" factors were recorded as 11 categories, including: infectious diseases, nervous system, ENT (ear, nose, and throat), respiratory, gastrointestinal, skin/subcutaneous tissue, musculoskeletal/connective tissue, obstetric, injury/poisoning, requires immunizations, and other (Nugent, 2009). However, for this study, the categories for "diagnosis" were summarized in three categories that included: infectious diseases, immunizations, and other (which included a combination of the remaining categories).

In order to analyze whether or not children attending the clinic for a "well-child check-up" as opposed to attending for some medical reason, the original categories as recorded by the HSC were used. Two categories were used, and included: "yes" or "no" that the child attended the clinic for a well-child check-up (Nugent, 2009).

\section{OHIP status.}

As seen in Figure 1, the original HSC research recorded the OHIP status of each Canadian child, and split the data into eight categories. The same categories were presented and analyzed for this study and include: lost health card; have current health card; expired health card; applied for OHIP; ineligible for OHIP; landed immigrant status in the three-month waiting period; returning Canadian in 
the three-month waiting period; or either no explanation was documented or another explanation was recorded (Nugent, 2009).

\section{Data}

Dr. Zoe Nugent led researchers at the Hospital for Sick Children (HSC), and collected data on 845 children $(1,262$ clinic visits) that attended the Clinic in eastern Toronto, Ontario between $2005-2009$. Of the 1,262 child visits, 13 percent were by Canadians; 41 percent were by landed immigrants; 5 percent were by refugees; 31 percent were by temporary residents; 5 percent were by undocumented children; and 5 percent did not have a recorded status in their clinic charts or in public health nurse notes (Nugent, 2009).

A sub-set of the data collected by researchers at the HSC was analyzed for this current study, specifically the data pertaining to Canadian children that attended the clinic between 2005-2009. Approximately 128 Canadian children (168 clinic visits) attended this clinic for the first time; 75 percent of them being Canadian-born and 25 percent being naturalized Canadians. Although these children were legal Canadian citizens, they were found to have varying OHIP statuses. Refer to Figure 1 to see the percentage of the 128 Canadian children with varying OHIP statuses. 
Figure 1: OHIP Status of Canadian Children at the Clinic (2005-2009)

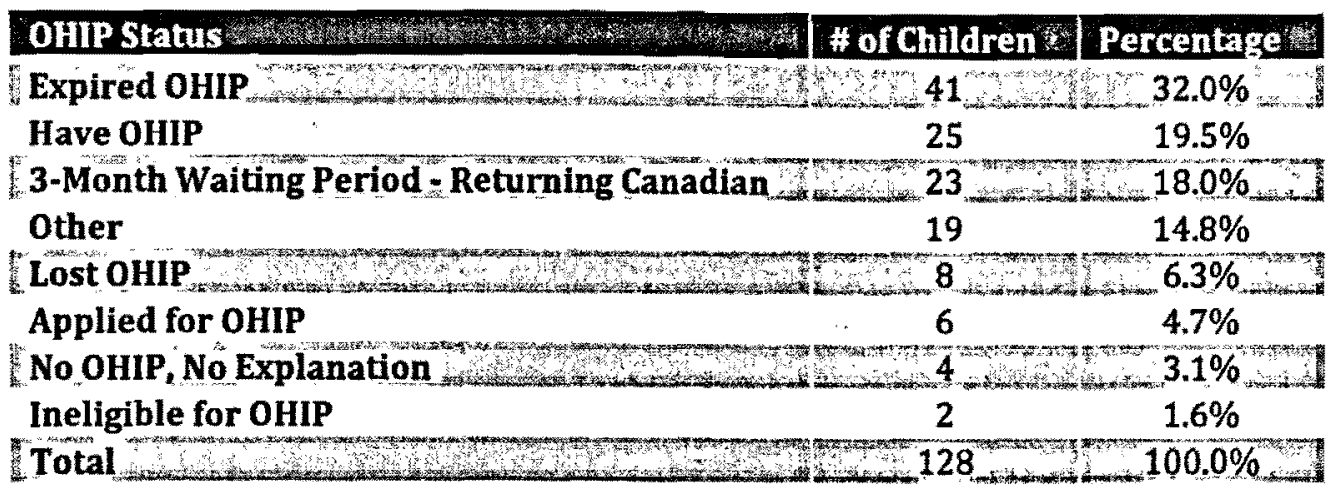

(Nugent, 2009)

\section{Ethics Approval}

The research team led by Dr. Zoe Nugent, from the HSC provided the data utilized in this study. The study conducted to obtain the primary data, was approved by the Hospital for Sick Children Research Ethics Board on March 1, 2011. Ryerson University Research Ethics Board approved the current study to utilize the aforementioned as secondary data on May 25, 2011.

\section{Research Design and Data Collection Process}

This empirical study consists of a quantitative analysis of secondary data. The American Psychological Association defines empirical studies as "reports of original research" and "include secondary analyses that test hypotheses by presenting novel analyses of data not considered or addressed in previous reports" (APA, 2010, p.10). Since "secondary analysis involves the use of data that were gathered for previous research studies or other primary purposes (eg., medical records, databases from surveys)" (Kielhofner, 2006), this study will follow the design for secondary analysis of existing dạta. 
Dr. Zoe Nugent and researchers from the Hospital for Sick Children (HSC). conducted the original research in 2009. They obtained data on all children attending the Clinic between 2005-2009, including: demographic factors (age at visit, gender, region by postal code); medical factors (presenting symptoms, past medical history, last known visit to a doctor, diagnosis, investigations, treatment, outcome); and social factors (country of origin, parents' origin, principal language, countries travelled through, status, OHIP coding, length of time in Canada, living arrangements, and education). Refer to Appendix A for the template used to collect paediatric patient data. Data was collected from two sources; patient medical charts and public health nurse notes. Volunteer medical residents and paediatric physicians recorded information found within patient medical charts, while volunteer nurses from the Clinic completed public health nurse notes. A summary of some of the original research as conducted by the HSC research team, can be seen in Figure 2 below.

Figure 2: Paediatric Population (2005-2009) at the Clinic

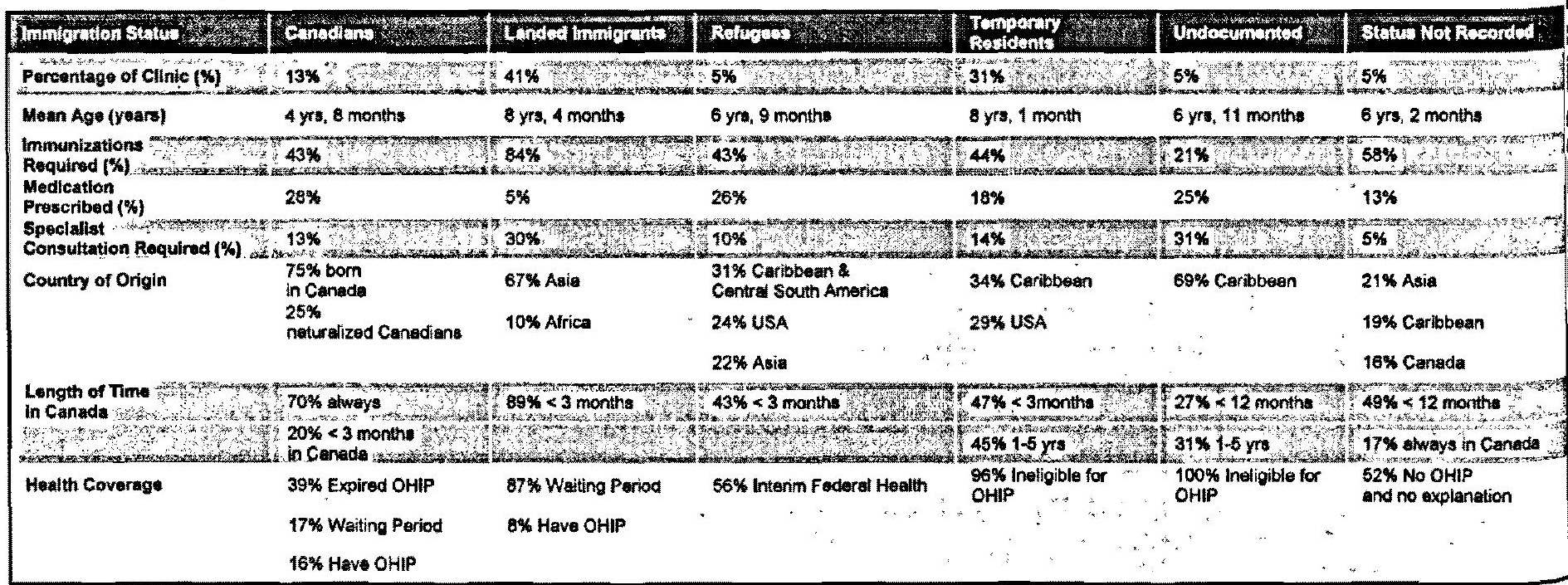

[Nugent, 2009] 
For this study, additional data was collected on 12 of the 128 Canadian children, since these children had parental or family-member immigration status available at the Clinic. In order to collect this information, the patient files identified as "Canadian children" by the HSC researchers, were retrieved and matched to family members who attended the Clinic as well. Descriptive information, combining both secondary data from the HSC and primary data from this study can be found in Figure 12, in Chapter 4 of this paper.

\section{Sampling.}

The HSC researchers began to analyze the overall demographic, medical, and social characteristics of the paediatric population from the clinic, as well as the between-group differences of all five categories of paediatric patients (Canadian, landed immigrants, refugees, temporary residents, and undocumented children] in their paper, entitled - Children without medical insurance in a Canadian metropolitan city (Nugent et al., 2011).

Their initial data notably revealed that numerous children living in eastern Toronto are ineligible for OHIP (Nugent, 2009). Through ongoing collaborative discourse between the original HSC researchers and the Ryerson University Master of Arts in Early Childhood Studies team, it was determined that within-group differences would be analyzed; more specifically, within-group differences amongst the Canadian children $(n=128$ or 13 percent of the paediatric population between 2005-2009). The reason the Canadian group was chosen, as opposed to landed immigrants, refugees, temporary residents, or undocumented children was strategic. Immigration status in Canada tends to be a controversial and subjective issue, consisting of a variety of opinions and attitudes. However, regardless of one's 
views on Canadian immigration, we can all agree that every Canadian child is both morally and legally entitled to public medical insurance coverage. While there are very concrete moral and legal arguments supporting all children's right to health care (including immigrant, refugee, temporary resident, and undocumented children], it is hard to believe that any person could disregard the empirical evidence pertaining to Canadian children as presented in this study.

\section{Data analysis.}

Due to the limited sample size $(n=128)$ of Canadian children, descriptive statistics were organized into frequency distribution figures to present the data. These figures were summarized and analyzed to generate findings about the data. It is essential to note that since inferential statistics were not utilized in this study, generalizations about the population that attended the Clinic cannot be made. However, for the purposes of this study, descriptive statistics were sufficient in demonstrating that the rights of Canadian children to health care are being neglected in Canada.

\section{Rationale for initial visit data.}

The original research by the HSC researchers contained information on 168 cumulative paediatric visits (Nugent, 2009). Therefore, some of the data was doubled, tripled, or quadrupled for the same patients who attended the clinic multiple times. For example, a child may have attended the clinic at age two, age four, and again at age seven. At age two and four, they may have required immunizations and lacked OHIP and access to Ontario health care. But, by age six, 
they may have obtained OHIP, and only returned to the clinic for a well-child check-up as they accompanied their unwell brother and undocumented mother. The fact that at some point in a Canadian child's life, they did not have access to health care in Canada was the focus of this study, but may have been overlooked by multiple data points. Furthermore, including 168 visits $(n=168)$ versus 128 children $(\mathrm{n}=128)$ would have confounded the data needed for this study. Therefore, only data from the initial visit were used.

\section{Data reliability and validity.}

Data validity and reliability are important concepts to consider when conducting research. Kielhofner (2006) defines validity as: "whether an instrument measures what it is intended to measure" (p. 29), and reliability as: "whether a given instrument provides stable information across different circumstances"

$\therefore$ (p. 30). Since the research team at the HSC collected the primary data, it would be dissolute to guarantee that controls were taken to ensure valid and reliable data collection. However, with the Hospital for Sick Children being a distinguished leader in health research, it can be assumed that appropriate measures were taken to ensure reliability and validity of data.

\section{Organization of Chapter 4: Results Section}

In the next section of this paper, the descriptive results will be presented in the form of frequency distribution tables. The results will be organized according to the factors (demographic, immigration, and health-related) that were analyzed in relation to the Canadian children that attended the Clinic between 2005-2009. 
Demographic factors presented include: age at initial visit, and gender. Immigration factors presented include: region of origin, principal language spoken, living arrangement, and length of time in Canada. Health-related factors presented include: well-child check-up, and diagnosis. Next, four findings will be presented based on the data. Finally, data on twelve of the 128 Canadian children living in mixed-status families will be introduced. 


\section{Chapter 4: Results}

\section{Secondary Data}

The sub-set of secondary data analyzed for this study included demographic, immigration, and health-related factors pertaining to the 128 Canadian children who attended the Clinic for the first time between 2005-2009 (Nugent, 2009). Frequency distribution tables are displayed below as descriptive statistics to represent this specific paediatric population. Subsequently, four specific findings are introduced based on the data. Finally, Figure 12 summarizes information pertaining to a sub-set of the 128 Canadian children and their mixed-status families $(n=12)$.

When reviewing and interpreting the results, it is imperative to take into account that all of the data refer to the initial visits of each child, as subsequent visits were excluded to avoid data misrepresentation. Furthermore, some data within patient charts and public health nurse notes are missing with respect to the variables relating to this study. This may be due to the absence of patient files, evolving methods of recording patient information at the Clinic, or varying degrees of documentation by different health care professionals who volunteered at the Clinic. Therefore, the ' $n$ ' (number of children) differs between frequency figures, but is specified for each.

\section{Demographic Factors}

Article 1 of the UNCRC defines a child as "every human being below the age of eighteen years unless under the law applicable to the child, majority is attained earlier (UN, 1989/1991). This definition applies to the collection of data from the 
Clinic. The ages of 127 out of 128 children were recorded, and are summarized in Figure 3. Of the 127 Canadian children with recorded age and gender at the initial clinic visit, the majority were toddlers, followed by children, infants, preschool, teens, and then neonates. The children were an almost even proportion of males (44.9 percent) and females ( 55.1 percent).

Figure 3: Canadian Child Age at Initial Clinic Visit

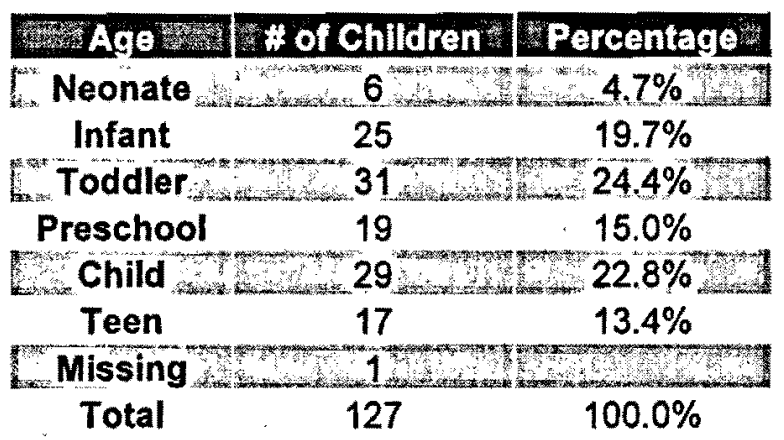

$$
\begin{gathered}
\text { Neonate }=<1 \text { month old } \\
\text { Infant }=1-11 \text { months old } \\
\text { Toddler }=12-35 \text { months old } \\
\text { Preschool }=36-59 \text { months old } \\
\text { Child }=5-11 \text { years old } \\
\text { Teen }=12-17 \text { years old }
\end{gathered}
$$

(Nugent, 2009)

While an almost equal distribution of male and female Canadian children attended the clinic between 2005-2009, the majority of them were within the categories of infant, toddler, preschool, and child. Yet, only 13.4 percent were teens, and only 4.7 percent neonates (Nugent, 2009). Perhaps neonates are sufficiently cared for in the hospital setting in which they are often born, making it unnecessary for their parents to access clinics for uninsured patients. Teens, on the other hand may be independent enough to determine methods of accessing health care on their own, without requiring assistance from their parents. However, infants, toddlers, preschool-aged, and children rely on their parents for their primary needs, such as health care: 


\section{Immigration Factors}

Child's region of origin and principal language spoken.

Of the 124 recorded regions of origin, most of the children were

Canadian-born ( 73 percent), followed by naturalized Canadians ( 27 percent) who originated in Asia, Africa, the Caribbean, the United States of America (USA), and South America and Europe (refer to Figure 4 below). Only 84 children had data recorded for their principal language spoken. Of the 84 children, 59 of them predominantly spoke English (refer to Figure 5 below) (Nugent, 2009).

Figure 4: Canadian Child Region of Origin

\section{Region of Origin n n}

Africa

Asia $\quad 15 \quad 12.0 \%$

[Caribbean_wat $5=4.0 \%$

Europe $\quad 1 \quad 0.8 \%$

North America
(Canada]

$\therefore$ North America

$\begin{array}{lcc}\text { (USA) } & 3 & 2.4 \% \\ \text { South America } & 1 & 1 \\ \text { Missing } & 4 & 0.8 \% \\ \text { Total } & 4 & 124\end{array}$

(Nugent, 2009)
Figure 5: Canadian Child Principal Language Spoken

Language

Spanish

Slavic languages $\quad 1 \quad 1.2 \%$

Arabic - - 6 - $71 \%$,

$\begin{array}{lll}\text { Bengali } & 1 & 1.2 \%\end{array}$

Gujarati_m

Farsi : $11.2 \%$

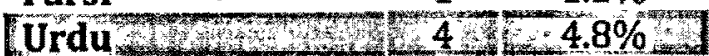

$\begin{array}{lll}\text { Korean } & 2 & 2.4 \%\end{array}$

[Chinese

Tagalog $2 \quad 2.4 \%$

English H 5 - $50.2 \%$

$\begin{array}{lll}\text { French } & 2 & 2.4 \%\end{array}$

Missing 44 M

$\begin{array}{lll}\text { Total } & 84 & 100.0 \%\end{array}$

(Nugent, 2009)

\section{Length of time in Canada and living arrangements.}

The majority ( 65 children) of the 90 Canadian children had always lived in

Canada, while 21 children had been living in Canada for less than three months. The remainder of Canadian children had been living in Canada for six to twelve months (two children), two to five years (one child), and more than five years (one child) 
(refer to Figure 6). Of the 72 Canadian children who reported living arrangements, 16 were living in shelters (refer to Figure 7) (Nugent, 2009).

Figure 6: Canadian Child Length of Time in Canada

\begin{tabular}{|l|c|c|}
\hline $\begin{array}{l}\text { Length of Time } \\
\text { in Canada }\end{array}$ & $\mathrm{n}$ & $\%$ \\
\hline < 3 months & 21 & $23.3 \%$ \\
\hline 6 - 12 months & 2 & $2.2 \%$ \\
\hline 2 - 5 years & 1 & $1.1 \%$ \\
\hline > 5 years & 1 & $1.1 \%$ \\
\hline Always & 65 & $72.2 \%$ \\
\hline Missing & 38 & \\
\hline Total & 90 & $100.0 \%$ \\
\hline
\end{tabular}

(Nugent, 2009)

Health Factors

\section{Diagnosis.}

Diagnostic information was recorded for 75 of the children. The diagnostic categories that may present transmissible risk to society are displayed in Figure 8 (below). For example, 40 of the 75 children required immunizations, and 14 of the children were diagnosed with infectious diseases (Nugent, 2009).

Figure 8: Canadian Child Diagnosis $(n=75)$

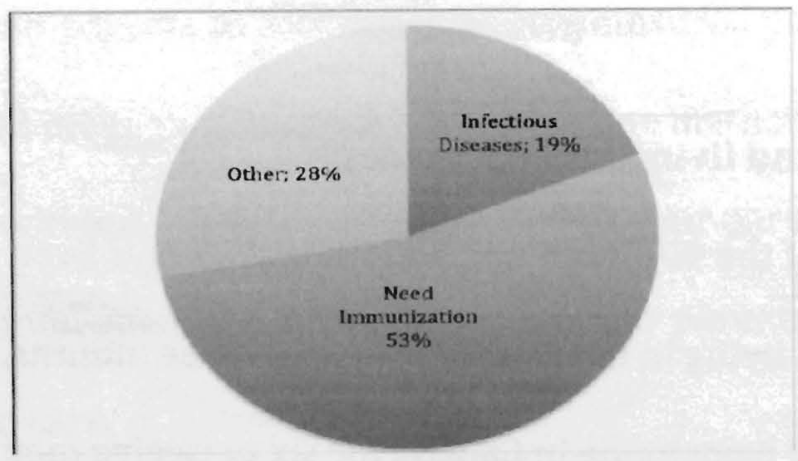

(Nugent, 2009)
Figure 7: Canadian Child Living Arrangements

\begin{tabular}{|l|c|c|}
\hline Living Arrangement & $\mathrm{n}$ & $\%$ \\
\hline Apartment & 36 & $50.0 \%$ \\
\hline House & 3 & $4.2 \%$ \\
\hline Sharing & 17 & $23.6 \%$ \\
\hline Shelter & 16 & $22.2 \%$ \\
\hline Missing & 56 & \\
\hline Total & 72 & $100.0 \%$ \\
\hline (Nugent, 2009) & & \\
\hline
\end{tabular}

Note: "Sharing" refers to living with another family or with relatives. 


\section{Findings}

(1) The health of Canadian children.

Canadian children who attend the Clinic do so because they are sick; they are there to access treatment. The data supports this claim since of the 121 Canadian children who attended the clinic between 2005-2009, 108 of them were sick and only 13 of them were well at the time of their visit (refer to Figure 9 below) (Nugent, 2009)

Figure 9: Canadian Well-child Check-Up

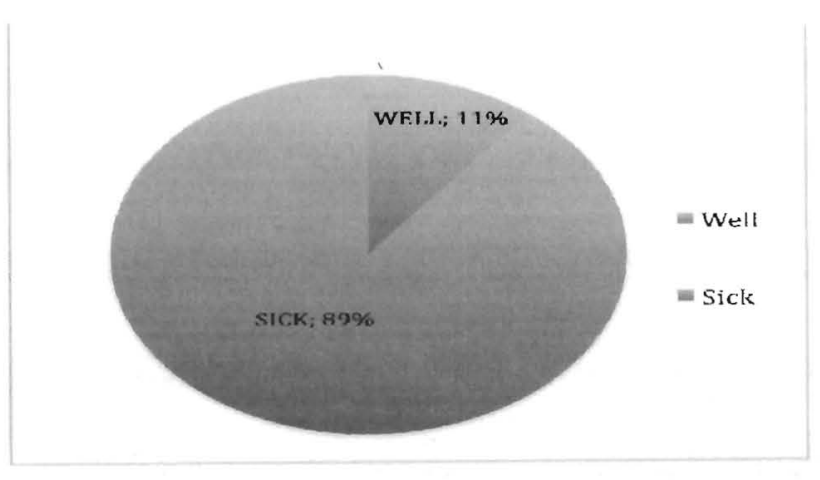

(Nugent, 2009)

\section{(2) OHIP status of Canadian children living in Ontario.}

Contrary to the dominant belief that all Canadian children are covered by health insurance, many Canadian children are in fact, uninsured. Of the 128 children, only 25 had valid OHIP cards, while 41 had expired OHIP, 23 were returning Canadians and waiting the three month period, 19 had "other" status recorded, eight lost their OHIP card, six were in the process of applying for OHIP, four did not have OHIP or an explanation recorded, and two were ineligible for OHIP altogether (refer to Figure 10) (Nugent, 2009). 
Figure 10: Canadian Child OHIP Status

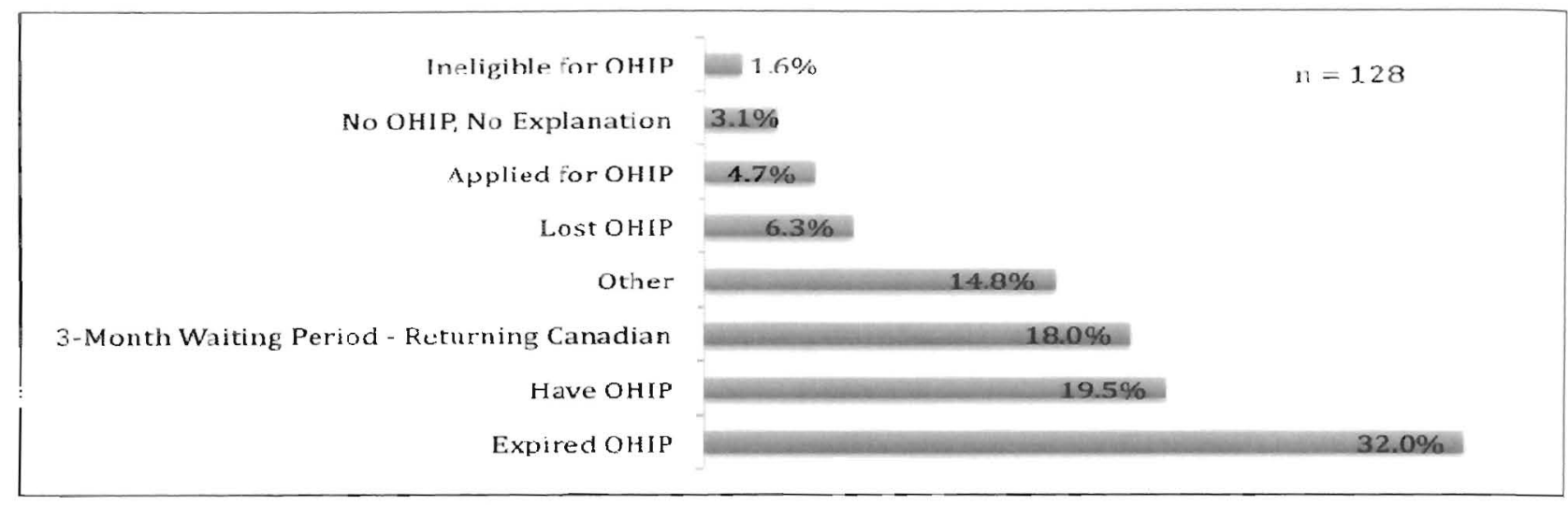

(Nugent, 2009)

\section{(3) Canadian-born and naturalized Canadian children in Canada.}

The issue of uninsured children impacts both Canadian-born children and naturalized Canadian children alike. As seen in Figure 11, both Canadian-born children and children that originated from other countries (and naturalized in Canada) have varying OHIP status.

Figure 11: OHIP Status * Regions of Origin

\begin{tabular}{|l|r|r|r|}
\hline \multirow{2}{*}{ OHIP STATUS } & \multicolumn{3}{|c|}{ Regions of origin } \\
\cline { 2 - 4 } & $\begin{array}{c}\text { Canada \& } \\
\text { USA }\end{array}$ & $\begin{array}{c}\text { Other } \\
\text { countries }\end{array}$ & Total \\
\hline Has OHIP & 18 & 7 & 25 \\
\hline Does not have OHIP & $19.4 \%$ & $22.6 \%$ & $20.2 \%$ \\
\hline 3 month waiting period & 63 & 12 & 75 \\
\hline Total & $12.9 \%$ & $38.7 \%$ & $60.5 \%$ \\
\hline
\end{tabular}

Refer to Appendix $\mathrm{C}$ for a list of "other" regions of origin.

(Nugent, 2009) 


\section{(4) Canadian children in mixed-status families.}

A group of Canadian children living in mixed-status families are accessing health care facilities for medically uninsured patients. For this study, information on family members was obtained for 12 Canadian children who attended the Clinic between 2005-2009 through primary data collection. Parental and/or sibling information was only available for the family members who also attended the Clinic. Therefore, if a child attended the clinic but their parent or sibling was not a patient there, it would be unlikely that any parental and/or sibling information was available for that child.

All 12 of the children documented were Canadian, and lived in a mixed-status family. Information on one neonate, five infants, four toddlers, one preschool, and one child were obtained. Of the 12 children with information, four children (33 percent) required immunizations at their time of visit, and two children (17 percent) were diagnosed with an infectious disease. Refer to Figure 12 on the following pages. 
Figure 12: Parental and Sibling Immigration Status of Canadian Children at the Clinic

\begin{tabular}{|c|c|c|c|c|c|}
\hline Child & Age & $\begin{array}{l}\text { Reason at } \\
\text { clinic/Diagnosis }\end{array}$ & $\begin{array}{l}\text { Child's } \\
\text { Immigration } \\
\text { Status }\end{array}$ & Child's OHIP Status & $\begin{array}{l}\text { Parent's } \\
\text { Immigration } \\
\text { Status at time } \\
\text { of child's visit }\end{array}$ \\
\hline 1 & Toddler & Needed immunizations & Canadian & Expired OHIP & $\begin{array}{l}\text { Mother and } \\
\text { Father: } \\
\text { Applying for } \\
\text { status as landed } \\
\text { immigrants }\end{array}$ \\
\hline 2 & Infant & Not recorded & Canadian & Other & $\begin{array}{l}\text { Mother and } \\
\text { Sister: Applying } \\
\text { for status as } \\
\text { landed } \\
\text { immigrants }\end{array}$ \\
\hline 3 & Infant & Needed immunizations & Canadian & Other & $\begin{array}{l}\text { Mother: Visitor } \\
\text { in Canada }\end{array}$ \\
\hline 4 & Infant & Needed immunizations & Canadian & 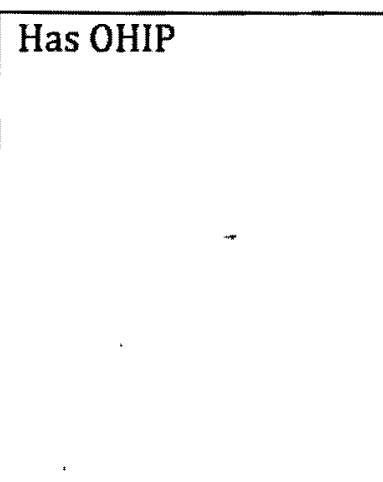 & $\begin{array}{l}\text { Mother: } \\
\text { Sponsored by } \\
\text { husband; in } \\
\text { Canada for four } \\
\text { years } \\
\text { Brother: } \\
\text { Undocumented } \\
\text { status }\end{array}$ \\
\hline 5 & Toddler & Other diagnosis & Canadian & Lost OHIP & $\begin{array}{l}\text { Mother and } \\
\text { Sister: Applying } \\
\text { for status as } \\
\text { landed } \\
\text { immigrants } \\
\text { Brother: } \\
\text { Applying for } \\
\text { sponsorship }\end{array}$ \\
\hline 6 & Toddler & Not recorded & Canadian & Has OHIP & $\begin{array}{l}\text { Mother: Visitor } \\
\text { in Canada for } \\
\text { one year }\end{array}$ \\
\hline
\end{tabular}




\begin{tabular}{|c|c|c|c|c|c|}
\hline Child & Age & $\begin{array}{l}\text { Reason at } \\
\text { clinic/Diagnosis }\end{array}$ & $\begin{array}{l}\text { Child's } \\
\text { Immigration } \\
\text { Status }\end{array}$ & Child's OHIP Status & $\begin{array}{l}\text { Parent's } \\
\text { Immigration } \\
\text { Status at time } \\
\text { of child's visit }\end{array}$ \\
\hline 7 & Neonate & $\begin{array}{l}\text { Skin/ } \\
\text { Subcutaneous tissue }\end{array}$ & Canadian & Has OHIP & $\begin{array}{l}\text { Mother: } \\
\text { Undocumented } \\
\text { status }\end{array}$ \\
\hline 8 & Pre-school & $\begin{array}{l}\text { Musculoskeletal/ } \\
\text { Connective tissue }\end{array}$ & Canadian & Expired OHIP & $\begin{array}{l}\text { Mother: } \\
\text { Temporary } \\
\text { resident; } \\
\text { waiting for } \\
\text { permanent } \\
\text { status }\end{array}$ \\
\hline 9 & Toddler & Infectious disease & Canadian & Expired OHIP & $\begin{array}{l}\text { Mother: } \\
\text { Undocumented } \\
\text { status; Aunt } \\
\text { plans to } \\
\text { sponsor } \\
\text { Brother: } \\
\text { Expired OHIP; } \\
\text { lost birth } \\
\text { registration }\end{array}$ \\
\hline 10 & Child & $\begin{array}{l}\text { Infectious disease/ } \\
\text { Short course medication }\end{array}$ & Canadian & Expired OHIP & $\begin{array}{l}\text { Mother: } \\
\text { Undocumented } \\
\text { status; Aunt to } \\
\text { sponsor } \\
\text { Brother: } \\
\text { Expired OHIP; } \\
\text { lost birth } \\
\text { registration }\end{array}$ \\
\hline 11 & Infant & Needed immunizations & Canadian & Expired OHIP & $\begin{array}{l}\text { Mother: } \\
\text { Undocumented } \\
\text { status; Husband } \\
\text { to sponsor }\end{array}$ \\
\hline 12 & Infant & Not recorded & $\begin{array}{c}\text { Canadian } \\
1\end{array}$ & $\begin{array}{l}\text { No OHIP; No } \\
\text { explanation } \\
\text { recorded }\end{array}$ & $\begin{array}{l}\text { Undocumented } \\
\text { status }\end{array}$ \\
\hline
\end{tabular}




\section{The Next Section}

The next and final chapter of this paper will include discussions of the results and implications of the findings presented in this chapter. Subsequently, conclusions will be drawn, future research ideas will be presented, and the value that this study has to the field of Early Childhood Studies will be discussed. 


\section{Chapter 5: Discussion and Conclusion}

\section{Discussion of Results}

\section{Health-seeking behaviours.}

This study reveals that parental immigration status might be a contributing factor to their health-seeking behaviours. When analyzing the data, the first question was: Why are Canadian children attending a health clinic for medically uninsured patients? Initially, it was assumed that this population of children did not have OHIP, which was the reason they attended this particular clinic. However, after realizing that 19.5 percent of the children that attended the Clinic did in fact have OHIP coverage, the next question became: Why would Canadian children with OHIP coverage attend a health clinic for medically uninsured patients? Furthermore, why had the parents of the 32 percent of children with expired OHIP and 6.3 percent of the children that lost their OHIP not renewed their child's coverage? This question has been left unanswered, as further investigation is required. Subsequently, data was obtained on 12 of the Canadian children living in mixed-status families (in Figure 12), leading to questions regarding Ruiz-Casares et al.'s (2010) argument. Ruiz-Casares et al. (2010) said that although Canadian children are eligible for health coverage and care, their parents' fear of the consequences that seeking health care might have on their own immigration status, prevents them from obtaining necessary documentation for their children. Do Canadian children in fact attend the Clinic because of their parents' health-seeking behaviours, as a consequence of their parents' immigration status? Again, this question remains unanswered, and requires further examination. 


\section{Implications of findings.}

\section{(1) The health of Canadian children.}

The first claim that Canadian children attend the Clinic because they are sick was supported by the data. The data suggest that for whatever reason, these parents wait until their child is ill before seeking medical support. This is a significant concern for the individual child due to the negative impact that delayed medical care has shown to have on short and long-term health (Ruiz-Casares et al., 2010; Weissman et al., 1991). This is a significant concern to society because healthy Canadian children are frequently exposed to sick Canadian children at school, or in other public facilities. This puts all members of society at an increased risk of falling ill with transmittable illness and disease. In addition, the financial burden of providing delayed medical care is detrimental to society as well.

Furthermore, data pertaining to diagnoses of the Canadian children in this study is alarming (as seen in Figure 8). The fact that 53 percent of the children documented $(n=75)$ required immunizations and 19 percent were diagnosed with infectious diseases makes one consider the following question: How far is the health care system protecting these children and other children they may come in contact with? Both the prevention of infectious disease through immunization, and the treatment of infectious disease that has already developed are methods to reduce transmissibility of harmful illness within society. As mentioned in Chapter 2 of this paper, Chabot et al. (2004) explain the importance of childhood immunizations in preventing, eliminating, or reducing common childhood infectious diseases in order to sustain optimal health. They further argue that immunizations are not only 
beneficial to individual children, but also to the general community for two reasons; disrupting the transmission of disease, and through the cost-effectiveness of disease prevention. However, if children are unable to access health care services to prevent and treat these diseases, community exposure increases, resulting in extensive health and financial burdens on society.

\section{(2) OHIP status of Canadian children living in Ontario.}

The second claim that many Canadian children are uninsured was supported by data and should raise questions about the true "universality, portability, and accessibility" of health care services for Canadian citizens, as the Canada Health Act states. In addition, just because a Canadian child has health insurance, does not mean they will access health care facilities that require OHIP. For example, multiple Canadian children attended the Clinic for medically uninsured individuals despite having health coverage. This places a financial burden on the Canadian health care system, since insured patients continue to utilize resources that have been reserved specifically for uninsured patients.

Lastly, the fact that 23 children were returning Canadians and had to wait three months to obtain OHIP is an injustice and a clear violation of the UNCRC, which guarantees a child's right to access health care services; the Canada Health Act, which guarantees reasonable access to insured health services; and the Canadian Charter of Rights and Freedoms, which guarantees protection from discrimination (including discrimination based on immigration status). 


\section{(3) Canadian-born and naturalized Canadian children in Canada.}

The third claim was that being medically uninsured in Ontario impacts both Canadian-born children and naturalized Canadian children. In 2007, Bernhard et al. said that: "An unknown but not insignificant portion of the Canadian population, including vulnerable children, is accessing far fewer of the benefits available in Canadian society than they might reasonably expect" (p. 113). The aforementioned finding identifies a distinct group of Canadians that do access fewer medical resources than expected, especially in view of the fact that they are Canadian citizens.

\section{(4) Canadian children in mixed-status families.}

Bernhard et al. (2007) state that:

"It is crucial to highlight here a group that is particularly disadvantaged: the Canadian-born children of individuals with uncertain status. Although these children are born in Canada and have rights as citizens, they seem to acquire their parents' precarious status rather than having their citizenship as their status" (p.113).

The fourth claim that a group of Canadian children living in mixed-status families are accessing health care facilities for medically uninsured patients reiterates Bernhard et al.'s assertion. All twelve of the documented children in Figure 12 have parents or siblings with precarious legal status, such as those applying as landed immigrants, visitors, sponsorship, and those that are undocumented. This small group of children may indicate that there is a larger cohort of Canadian children living in mixed-status families who have acquired their parents' precarious status. 


\section{Conclusions}

Future directions and recommendations in policy, practice, \& research. Role of paediatricians.

Canada's commitment to the UNCRC must be embedded in all Canadian health care policies to guide healthcare practitioners in fulfilling their legal obligation to the welfare of all children. Waterston and Goldhagen (2006) emphasize the tremendous influence that paediatricians have on children, society, and the government. Lansdown (2000) claims that paediatricians have a responsibility to advocate for fulfilling the social, economic, and political well-being of children in order to guarantee all children's access to quality health care. Webb et al. (2009) suggest that paediatricians must play an important role in improving the health and health care of children through training, raising awareness of children's rights, and through being continually audited and held accountable for their involvement in ensuring that children's rights are upheld. Raman et al. (2007) remind us that the field of paediatrics arose from advocacy efforts, in which doctors caring for children realized the differing needs between adults and children. They emphasize the impact that clinicians have made in fulfilling children's rights through advocacy movements in the past, and the importance of clinicians in holding governments accountable to their legal obligations to the health care of children. Therefore, a rights-based approach is necessary for paediatricians, and health care providers within their own practice, to train future generations of paediatricians, and to influence the government in fulfilling their legal obligations (Waterston \& Goldhagen, 2006). 
A particular example of a rights-based approach for Ontario paediatricians could be for them to employ a "know-your-rights-advocate" for their clinic. For example, at the Clinic, this person (either an employee or volunteer) could educate each parent about his or her child's right to health care. Furthermore, this person could assist parents of Canadian-born and naturalized Canadians in accessing useful resources, filling in OHIP forms, accessing translators, and explaining pertinent aspects of the UNCRC, CHA, and the CRF. Paediatricians at the Clinic would ensure that they directed each patient to the children's rights advocate at each visit. Furthermore, Ontario paediatricians could take the lead in advocacy groups, assist in applications to change institutional policies, and conduct and publish active research within the community.

\section{Modifications to OHIP eligibility. .}

Canadian public policy must serve the best interest of all children. OHIP qualifications must be modified to ensure immediate, publicly funded health coverage for all children. OHIP policy must be modified with a goal to discontinue discrimination against children who have parents of precarious status. Access to quality health care services for children with parents of precarious status must be guaranteed, regardless of whether or not a child has a health card.

The current Ontario health care system requires that the child's parents must attend a governmental office to provide the child's proof of Canadian citizenship, and parental proof of identity and residency in Ontario in order to obtain their child's health card. This requirement must be abolished. According to the UNCRC, a 
child is defined as "every human being below the age of eighteen years unless, under the law applicable to the child, majority is attained earlier" (UNCRC, 1989/1991). Therefore, a child's proof of citizenship and parental proof of identity and residency in Ontario is completely irrelevant to the child's legal entitlement to quality health care access and service. A child's proof of age is sufficient.

Next, the three-month waiting period for landed immigrants and returning Ontarians must be eradicated with respect to children and pregnant women. Recall the importance of neurological development during prenatal and early childhood and the detrimental effects that occur later in life for children deprived of health care early in life, as discussed in Chapter 2. Yet, currently, only newborns, protected persons, OHIP-eligible adopted children under 16 years of age, and persons moving to long-term care facilities in Ontario are exempt from the three-month waiting "period to qualify for immediate OHIP. To fulfill Canada's legal obligations and provide children with the means necessary for optimal development, all children and pregnant women must be exempt from waiting to qualify for OHIP.

\section{Immigration research.}

Research is necessary for the creation and modification of public policies and practice. Unfortunately, research that involves people living in Canada with precarious legal status is gravely neglected. As noted in Chapter 2, conducting research on this population is challenging (Bernhard and Young's, 2009). Governmental officials and university ethics boards need to re-evaluate their positions on the basis of a cost-benefit analysis of their policies. For example, the 
cost to society of not having information on this population may be greater than the need to prosecute immigrants who are undocumented. At least with further information, the Canadian government would know exactly what issues they are dealing with in relation to this group.

The government should consider removing the legal obligation of ethics boards to provide participant information upon court subpoena, since obtaining data on this particular population may be beneficial to Canadian society. $0 r$, if participant data must be provided to the courts, a guarantee that it will not be shared with Citizenship and Immigration Canada must be provided.

\section{Future directions and recommendations in the community.}

\section{Knowledge of children's rights and advocacy.}

Educators, academics, health care providers, government affiliates, and members of Canadian society must be familiar with the UNCRC, the Canada Health Act, and the Canadian Charter of Rights and Freedoms. They must all advocate on behalf of all children. Bernard et al. (2007) say that:

“...participants in our study were not clear about their children's rights, and, as a result, children's entitlements were curtailed. Similar to Young's report, we found participants greatly affected by the lack of key documents, especially health cards. Two of the most glaring gaps had to do with children's access to medical service and education" (p. 112).

It is the responsibility of those who are familiar with children's rights to educate and engage those who are unaware; whether they be health care providers, government affiliates, family members, friends, or neighbours. Parents require information on 
their rights and the rights of their children, and need to be educated on how to access health care for their children, including how to fill in forms and apply for OHIP successfully. They also need to be informed about resources they can access in the case that their rights or their child's rights have been denied.

\section{Collaboration.}

Educators, academics, health care providers, government affiliates, and members of Canadian society must collaborate as a community; in whatever capacity we can, to ensure that no child is deprived of his or her right of access to the highest attainable standard of health and health care services. We must acknowledge that many immigrant children, undocumented children, children with precarious legal status, and the children of immigrant parents are denied their right

-to health care in Canada every day, and that this undeniable circumstance is based within systemic discrimination and inequality and continues to be perpetuated by our silence and lack of action. We must write letters to the government, publish papers in academic journals, conduct active research within the community, and encourage our health care providers and policy-makers to hold the government accountable. We must educate others and ourselves on how to acquire and maintain a rights-based approach to encouraging the health and well-being of all children. Lastly, we must work together with oppressed groups, such as children with parents of precarious status. We must support them and promote their self-empowerment while they ensure that their rights are realized. 


\section{Future Research}

This study looked at the within-group differences of the Canadian children that attended the Clinic between 2005-2009. Future research could involve looking at the within-group differences of the other groups of paediatric patients that attended the clinic during the same time period. The other groups, as collected by the original HSC researchers, include: landed immigrants, refugees, temporary residents, and undocumented children (Nugent, 2009).

Another future study could utilize the address and postal code information obtained by the HSC researchers. Through the "City of Toronto", ward profiles for various wards within Toronto could be obtained to further describe (or even compare) the demographic, immigration, and other characteristics of the populations that access the Clinic.

Future research may also involve further analysis of the twelve Canadian children living in mixed-status families, as documented in Figure 12. Qualitative interviews could be conducted on these families to explore their perspectives and experiences in living in a mixed-status family. Furthermore, additional data could be collected from the charts of other Canadian children who have attended clinics for medically uninsured individuals, to either support or refute the findings in this study.

\section{Contribution of this Study \& Value to Early Childhood Education}

This study corroborates the fundamental work of Bernhard et al. (2007), who reported findings that parents' status is used to justify denying children's right 
to health care. Furthermore, similar to Bernhard et al. (2007), this study has identified Canadian children living in families with precarious status who appear to have acquired their parents' precarious status, as opposed to acquiring their own status as Canadian citizens. Additionally, this study reiterates Sigona's (2011) claim that precarious parental immigration status negatively impacts on children's access to health care services, even if they are Canadian-born and therefore, Canadian citizens, as well as Bernhard et al.'s (2008) claim that families with mixed legal status face vulnerabilities leading to negative social and health outcomes, even if the children are Canadian citizens. Finally, this study brings forward Ruiz-Casares et al.'s (2010) philosophy that even if children are Canadian and eligible for health coverage, their parents' fear of the consequences that seeking health care might have on their own immigration status prevents them from accessing services and "obtaining necessary documentation for their children.

This study contributes to filling the gap in the limited literature pertaining to the effects of parents' status on Canadian children living in these mixed-status families. Furthermore, since previous research in this field is predominantly qualitative-in-nature, the use of a quantitative methodology in this study initiated a path for future quantitative research in this understudied field.

This study, which looks at the health and well-being of Canadian children, is essential to the field of early childhood education for a variety of reasons. First, the exposure of unimmunized, unhealthy children to other children within the community is concerning. Next, with the constancy of Canadian immigration, it is our responsibility to ensure the rights of this special population. Finally, the simple 
fact that children are not receiving appropriate health services is an issue of social injustice.

\section{Closing Statement: A Child's Right to Health Care}

This paper was not written to argue for or against equality amongst citizen and non-citizen persons living in Canada. The goal was not to support or condemn illegal or undocumented citizenship status of people within Canada, nor was it to confer blame to any particular group of people, including health care providers, governmental affiliates, or immigrants of varying statuses.

This paper was written, however, to advocate for all children living in Canada and their right to health care, regardless of parental citizenship status, and regardless of whether or not parental choices were made in accordance with the child's best interest. As Bernhard and Young (2009) say, "when children are involved, we must take the high road and focus on children's wellbeing rather than on judging the moral correctness of their parents' or other adult individuals' actions" (p.178). Children's right to health care is not only of moral and ethical significance, but is that of legal stature. Denial of children's access to health care services in Canada violates the legal obligation of the Canadian government under the UNCRC to protect every child's right to health care (article 24). Furthermore, denial of the right to health care further infringes upon other legal rights of children, including but not limited to all four guiding principles of the UNCRC of a child's right to non-discrimination (article 2), best interest (article 3), life, survival and development (article 6), and participation (article 12) (UN, 1989/1991). In addition, 
denial of the right to health care violates the Canada Health Act and the Canadian Charter of Rights and Freedoms.

Axford (2009) introduced two types of rights that are necessary in improving child well-being; moral rights and legal rights. Moral rights persuade individuals and organizations to behave appropriately toward others, while legal rights demand compliance with regulations and hold individuals and organizations accountable through litigation and legal action. The fact that children living in Canada are not receiving health care services is morally reprehensible, but since moral rights are utilized for persuasion purposes, accountability is limited. However, with Canadian ratification of the UNCRC, the State must be held legally accountable for denial of children's right to health care. As Lansdown (2000) has stated, "Respect for children's rights cannot be perceived as an option, as a question of favour or "kindness to children, or as an expression of charity. Children's rights generate obligations and responsibilities that must be honoured." 


\section{Appendix A}

Data Entry Form for children at the Clinic: Designed and utilized by Dr. Zoe Nugent from the Hospital for Sick Children, to collect data in 2009 (Version 4 - 30-Jan-10)

Demographic

\begin{tabular}{|c|c|c|c|c|c|c|c|c|}
\hline 1. Age at visiti & & $\begin{array}{l}\text { Neonate } \\
{[<1 \mathrm{mo}]}\end{array}$ & $\begin{array}{l}\text { Infant [1- } \\
\text { 11mo] }\end{array}$ & $\begin{array}{l}\text { Toddler } \\
\text { [12-35mo }]\end{array}$ & $\begin{array}{l}\text { Pre-school } \\
\text { [36-59m] }\end{array}$ & $\begin{array}{l}\text { Child [5- } \\
\text { 11yr] }\end{array}$ & $\begin{array}{l}\text { Teen }[12- \\
17 y r]\end{array}$ & $\begin{array}{l}\text { Not } \\
\text { recorded }\end{array}$ \\
\hline 2. Gender & Male & Female & \begin{tabular}{l|l} 
Not \\
recor
\end{tabular} & & & & & \\
\hline 3. Region from postal code & \multicolumn{3}{|c|}{ East Toronto } & \multicolumn{2}{|c|}{$\begin{array}{l}\text { Outside East } \\
\text { Toronto }\end{array}$} & Outside GT & \multicolumn{2}{|c|}{ Not recorded } \\
\hline
\end{tabular}

Medical

\begin{tabular}{|c|c|c|c|c|c|}
\hline 4. Presenting symptomsii & & & & & \\
\hline 5. Past medical history & & & \multicolumn{2}{|c|}{ None } & Not recorded \\
\hline 6. Last known visit to doctor & \multicolumn{5}{|c|}{ Not recorded } \\
\hline \multicolumn{6}{|l|}{ 7. Diagnosisii } \\
\hline 8. Investigations & $\begin{array}{l}\text { Bedside } \\
\text { Urinalysis } \\
\beta-H C G\end{array}$ & Bloodwork & $\begin{array}{l}\text { Imaging } \\
\text { X-ray } \\
\text { Ultrasound } \\
\text { Other }\end{array}$ & Other & None recorded \\
\hline 9. Treatment & Advice & $\begin{array}{l}\text { Short course } \\
\text { medication }\end{array}$ & $\begin{array}{l}\text { Ongoing } \\
\text { medication }\end{array}$ & Other & None recorded \\
\hline 10. Outcome & Discharge & $\mathrm{F} / \mathrm{u}$ at $\mathrm{CHC}$ & Referral & ER & Other \\
\hline
\end{tabular}

Social

11. Country of origin [see Appendix A]

12. Parents' origin [see Appendix $\mathrm{A}$ ]

13. Principal language Isee Appendix B]

14. Countries travelled through [see Appendix A]

15. Statusiv

16. OHIP coding"

17. Length of time in Canada

\begin{tabular}{|l|l|}
\hline 18. Length of time for mother in & \\
\hline
\end{tabular}

Canada

19. Living arrangementsvi

20. Educationvii 
I Age categories: Neonate 0-1 month, infant 1-11 months, toddler $12-35$ months, pre-school 36-59 months, child 5-12 years, teenager $13-17$ years.

1 Symptoms:

1. Fever

2. Cold/coryza

3. Ear pain/ear discharge

4. Cough

5. Wheezing

6. Breathlessness

7. Episodes of stopping breathing

8. Stomach pain/colic

9. Vomiting

10. Diarthoea

11. Constipation

12. Blood in the stools

13. Rash

14. Seizures

15. Headache

16. Accident/injury

17. Needs immunisations

18. Well-child check-up

19. Other [describe]

Diagnosis:

1. Infectious diseases

2. Haematological

3. Endocrine, nutritional and metabolic

4. Mental and behavioural

5. Nervous system

6. Ophthalmological

7. ENT

8. Cardiovascular

9. Respiratory

10. Gastrointestinal

11. Skin/subcutaneous tissue

12. Musculoskelefal/connective tissue

13. Genitourinary

14. Obstetric

15. Congenital malformations, deformations, chromosomal abnormalities

16. Injury, poisoning

17. Needs immunisations

18. Other [describe]

19. Not recorded

' Public Health Nurse coding for Status:

1. Landed immigrant

2. Refugee claimant

3. Sponsored

4. Undocumented

5. Denied refugee

6. Expired refugee claim

7. Canadian

8. Applied for landed immigrant status

9. Denied landed immigrant status

10. Applied for refugee status

11. Student visa

12. Work visa

13. Visitor

14. Other

15. Not recorded

I PHN coding for OHIP:

1. 3 months wait for landed immigrant

2. Lost

3. Expired

4. Applied for 


\section{5. $\mathrm{IFH}$}

6. Nol eligible

7. 3 months wait in refurning Canadian

8. Has OHIP

9. Other

10. Not recorded

11. No OHIP - no explanation recorded

I PHN coding for Living Arrangement:
1. Apartment
2. House
3. Shelter
4. Sharing
5. No fixed address
6. Motel
7. Other
8. Not recorded

' PHN coding for Education:
1. Grade school
2. High school
3. No education
4. N/A
5. Other
6. Not recorded

\section{Appendix A - Country of Origin}

1. Afganistan

2. Africo N.E.S./AFRI

3 Albania/Albanie

4. Algeria/Algerie

5. Angola

6. Antigua-Barbuda

7. Arab Emirates/EMIR

8. Argentina/Argentin

9. Armenia

10. Aruba

11. Asia Nes.Asie NSA

12. Australia Nes/Aust

13. Australia/Australi

14. Austria/Autriche

15. Azerbaijon

16. Azores/Acores

17. Bahama lstands/Bah

18. Bahrain/Bahrein

19. Bangladesh

20. Barbados

21. Belarus

22. Belgium/Belgique

23. Belize

24. Benin Peoples Rep.

25. Bermuda/Bermudes

26. Bhutan/Bhoutan

27. Bolivia/Bolivie

28. Bosnia-Hercegovina

29. Botswana, Republic

30. Brazil/Bresil .

31. Brunei

32. Bulgaria/Bulgarie

33. Burkina-faso

34. Burundi

35. Cambodia

36. Cameroun

37. Canary islands/lle

38. Cape Verde/Cap-Ver 
39. Cayman islands/CAI

40. Cent Amer Nes/Amer

41. Central Africa Rep

42. Chad, Republic of

43. Chile/Chill

44. China-Mainland/Chi

45. Colombia/Colombie

46. Comoros/Etat Comor

47. Congo, Democratic R

48. Congo, People's Rep.

49. Cook Islands

50. Costa Rica

51. Crotia

52. Cuba

53. Cyprus/Chypre

54. Czech Republic

55. Denmark/Danemark

56. Djibouti. Rep. Of

57. Dominica/Dominque

58. Dominican Rep/Rep

59. Sgypt/Egypte

60. El Salvador

61. England/Angleterre

62. Equador/Equateur

63. Eritrea

64. Estonia/Estonie

65. Ethopia/Ethopie

66. Fij/Fidi

67. Finald/Finlande

68. Fr. Polynesia/Poly

69. France

70. French Guiana/Guya

71. Futuna Wallis

72. Fyr Macedonia

- 73. Gabon Republic

74. Gambia/Gambie

75. Georgia

76. Germany

78. Ghana

79. Gibralter

80. Greece/Grece

81. Greenland/Groenlan

82. Grenada/Granade

83. Guadeloupe

84. Guatemala

85. Guinea Rep of /Guin

86. Guinea-Equato/Guin

87. Guyana/Guyane

88. Haiti

89. Honduras

90. Hong Kong

91. Hong Kong Sar

92. Hungary/Hongrie

93. Iceland/siande

94. India/Inde

95. Indonesia/Indonesi

96. Iran

97. Iraq

98. Irish Republic/lin

99. Israel

100. Italy/ltalie

101. Ivory Coast, Republ

102. Jamaica/Jamaique

103. Japan/Japon

104. Jordan/Jordanie

105. Kazakhstan 


\author{
105. Kenya \\ 107. Korea Republic of \\ 108. Korea, People's Dem \\ 109. Kuwait/Koweil \\ 110. Kyrgzstan \\ 111. Laos \\ 112. Latvia/Letionie \\ 113. Lebanon/Liban \\ 114. Liberia \\ 115. Libya/Libye \\ 116. Lithuania/Lituanie \\ 117. Luxembourg \\ 118. Macao \\ 119. Madagascar/Madagas \\ 110. Maderia/Madere \\ 111. Malawi \\ 112. Malaysia/Malaisie \\ 113. Maldives Rep. Of \\ 114. Mali, Republic of \\ 115. Malta/Malte \\ 116. Martinique \\ 117. Mauritania/Maurita \\ 118. Mauritius/Maurice \\ 119. Mexico/Mexique \\ 120. Mo Dova \\ 121. Mongolia/Mongolie \\ 122. Monserrat \\ 123. Morocco/Maroc \\ 124. Mozambique \\ 125. Myanmar(Burma)/Mya \\ 126. N. Ireland/lrtande \\ 127. Nambia/Namibie \\ 128. Kaura/Napru \\ 129. Nepal \\ 130. Netherlands Antill \\ 131. Netherlands The/PA \\ 132. New Caledonia \\ 133. New Zealand/Nouvel \\ 134. Nicaragua \\ 135. Niger, Republic of \\ 136. Nigeria \\ 137. Norway/Norvege \\ 138. Oman \\ 139. Pakistan \\ 140. Palestinian Author \\ 141. Panama, Republic of \\ 142. Papua New Guinea \\ 143. Paraguay \\ 144. Peru/Perou \\ 145. Philippines Rep. Of \\ 146. Poland/Pologne \\ 147. Portugal \\ 148. Puerto Rico \\ 149. Qatar \\ 150. Reunion \\ 151. Roumania/Roumanie \\ 152. Russia \\ 153. Rwanda/Ruanda \\ 154. S. Africa Rep/Rep D \\ 155. A. Samoa West \\ 156. A. Saudi Arabia/Arabi \\ 157. Scotland/Ecosse \\ 158. Senegal \\ 15\%. Seychelles \\ 160. Sierra Leona \\ 161. Singapore/Singapou
}


162. Slovak Republic

163. Slovenia

164. Somalia, Democratic

165. Spain/Espagne

166. Sri Lanka

167. St. Kitts-Nevis/St

168. St. Vincent \& The G

169. St. Lucia/Ste. Luc

170. St. Pierre Miquelon

171. Sudan Dem Rep/Soud

172. Suriname

173. Swaziland

174. Sweden/Suede

175. Switzerland/Suisse

176. Syria/Syrie

177. Tadjikistan

178. Taiwan

179. Tanzania/Tanzanie

180. Thailand/Thailande

181. Togo Rep. Of

182. Tonga

183. Trinidad \& Tobago

184. Tunisia/Tunisie

185. Turkey/Turquie

186. Turkmenistan

187. Uganda/Ouganda

188. Ukraine

189. Uruguay

190. USSR/URSS

191. Uzbekistan

192. Vanuata

193. Venezuela

194. Vietnam Soc. Rep.

195. Virgin Islands/VIE

196. Wales/Gailes

197. Yeman Arab Rep.

198. Yugoslavia/Yougosl

199. Zambia/Zambie

200. Zimbabwe

201. North America

202. U.S.

203. Canada

204. Mexico

205. Central America

206. South America

207. Carribean basin

208. Europe

209. West

210. Central

211. East

212. Africa

213. East

214. West

215. Central

216. South

217. North

218. Mid East

219. Asia

220. West

221. Southeast

222. North

223. Pacific

224. Other

225. Not recorded 
1. Italian

2. Portugese

3. Romanian

4. Spanish

5. Romance languages, n.i.e.

6. Germanic languages

7. German

8. Yiddish

9. Netherlandic languages

10. Dutch

11. Flemish

12. Frisian

13. Scandinavian languages

14. Danish

15. Icelandic

16. Nonwegian

17. Swedish

18. Germanic languages, ni.e.

19. Celtic languages

20. Gaetic languages

21. Welsh

22. Celtic languages, ni.e.

23. Slavic languages

24. Bulgarian

25. Byelorussian

26. Croatian

27. Czech

28. Macedonian

29. Polish

30. Russian

31. Serbian

32. Serbo-Crotian

33. Slovak

34. Slovenian

35. Ukranian

36. Slavic languages, n.i.e.

37. Baltic languages

38. Latvian (Lettish)

39. Lithuanian

40. Finno-Ugric languages

41. Estonian

42. Finnish

43. Hungarian

44. Greek

45. Armenian

46. Turkic languages

47. Turkish

48. Turkish languages, n.i.e.

49. Semitic languages

50. Amharic

51. Arabic

52. Hebrew

53. Maltese

54. Somali

55. Tingringa

56. Semitic languages, n.i.e.

57. Indo-tranian languages

58. Bengali

59. Gujarati

60. Hindi

61. Konkani

62. Kurdish

63. Marathi

64. Pashto 


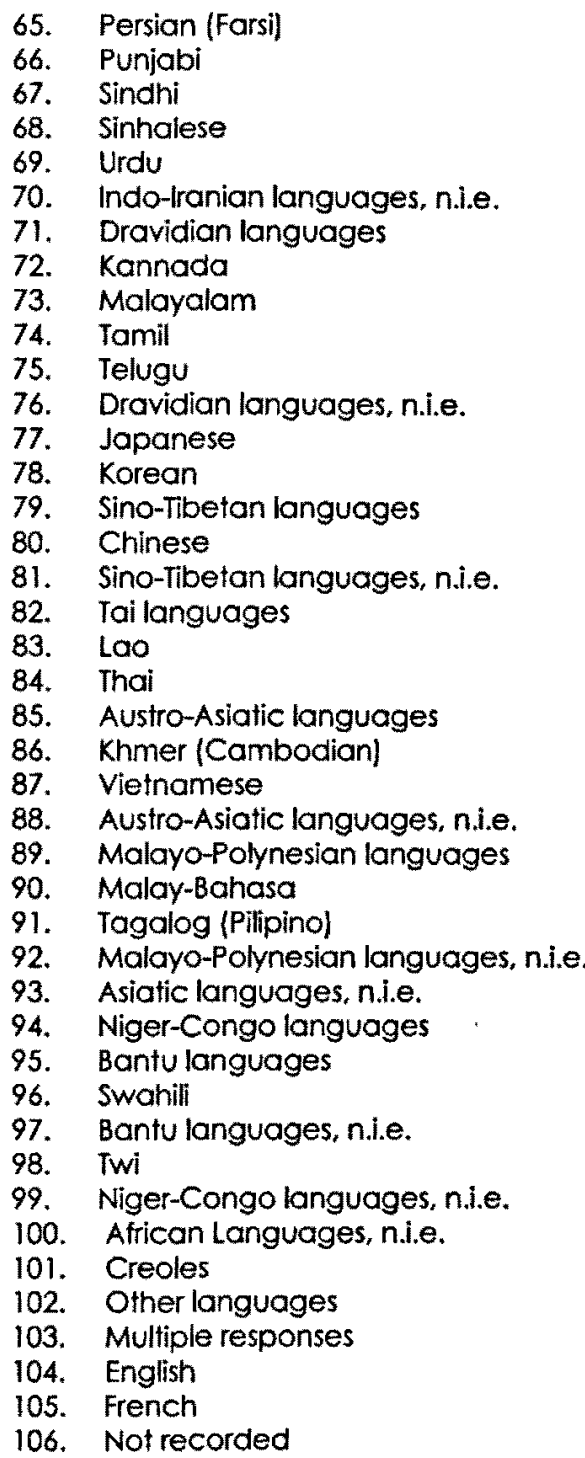

\section{Notes for Data Entry Form}

Sheet $1=$ each individual visit

Sheet 2 = each patient

$M$ (area $)-s=$ east Toronto, os = GTA outside east Toronto, ot $=$ outside GTA

$\mathrm{N}$ - history of presenting illness

0 - past medical history

$\mathrm{P}$ - no significant $\mathrm{PMH}$

$\mathrm{Q}-$ no $\mathrm{PMH}$ recorded

$S-$ diagnosis

$\mathrm{T}-\mathrm{Y}$ - investigations performed

$\mathrm{Z}-\mathrm{AE}$ - treatment given

AF-AK - disposition

AR-AZ - length of time in Canada

BA-BI - length of time for mother in Canada 


\section{Appendix B}

Included in the Data Entry Form for children at the Clinic:

Designed and utilized by Dr. Zoe Nugent from the Hospital for Sick Children, to collect data in 2009 (Version 4 - 30-Jan-10)

"Other" includes the following diagnoses:

Dermatological

Respiratory

Obstetric

Gastrointestinal

Injury-related

Mental or Behavioural

Ear, Nose and Throat

Musculoskeletal

Haematological

Nervous system

Ophthalmologic

Cardiovascular

Nutritional or Endocrine

Prescription refill, Allergic reaction, dental decay, fussy baby, poor appetite, growing pains, lymphadenopathy, fatigue, chest pain not yet diagnosed, obesity, failure to thrive, aberrant tooth 


\section{Appendix C}

Included in the Data Entry Form for children at the Clinic:

Designed and utilized by Dr. Zoe Nugent from the Hospital for Sick Children, to collect data in 2009 (Version 4 - 30-Jan-10)

"Other" includes the following countries of origin:

\section{Albania}

Arab Emirates

Bangladesh

China

Cuba

Egypt

Guyana

Hong Kong

India

Iran

Jordan

Kazakhstan

Kuwait

Martinique

* Nigeria

Pakistan

* St. Vincent

* St. Lucia

* Thailand 


\section{References}

Alexander, G., \& Korenbrot, C. (1995). The Role of Prenatal Care in Preventing Low Birth Weight. The Future of Children, 5(1), 103-120.

Ali, M. (2008). Loss of Parenting Self-efficacy among Immigrant Parents.

Contemporary Issues in Early Childhood, 9(2), 148-160.

American Psychological Association (APA). (2010). Publication Manual (6 ${ }^{\text {th }}$ Ed.).

Washington, DC: American Psychological Association.

Axford, N. (2009). Developing congruent children's services to improve child well-being. Child and Family Social Work, 14(1), 35-44.

Bernhard, J., Goldring, L., Young, J., Berinstein, C., Wilson, B. (2007). Living with uncertain legal status in Canada: Implications for the wellbeing of children and families. Refuge, 24(2), 101-113.

Bernhard, J., Landolt, P., \& Goldring, L. (2008). Transnationalizing Families: Canadian Immigration Policy and the Spatial Fragmentation of Care-giving among Latin American Newcomers. International Migration, 47(2), 3-31.

Bernhard, J., \& Young, J. (2009). Gaining Institutional Permission: Researching Precarious Legal Status in Canada. Journal of Academic Ethics, 7(3), 175-191.

Bettinger, J., Scheifele, D., Kellner, J., Halperin, S., Vaudry, W., Law, B., \& Tyrrell, G. (2010). The effect of routine vaccination on invasive pneumococcal infections in Canadian children, Immunization Monitoring Program, Active 2000-2007. Vaccine, 28(9), 2130-2136.

Bramham, D. (2011, March 3). Canadian kids denied basic services; Children of immigrant mothers who were abused can't access school, food, health care. The Vancouver 
Sun, pp. A1.

Bramham, D. (2011, March 11). Speaking up for the children who fall through the cracks; Lobby groups fight for Canadian-born offspring of abused mothers, undocumented immigrants who are denied health care, education. The Vancouver Sun, pp. A4.

Brock, D. (2001). Children's Rights to Health Care. Journal of Medicine and Philosophy, 26(2), 163-177.

Canadian Council on Social Development [CCSD]. (2006). Stats \& Facts: Demographic Profile of Canada. Retrieved February 5, 2011 from http://www.ccsd.ca/factsheets/demographics/

Canadian Council on Social Development [CCSD]. (2008). Growing Up in North America: The Economic Well-Being of Children in Canada, the United States, and Mexico. Retrieved February 5, 2011 from http://www.ccsd.ca/pubs/2008/cina/TriEcono_English.pdf

Case, A., Fertig, A., \& Paxson, C. (2005). The lasting impact of childhood health and circumstance. Journal of Health Economics, 24(2), 365-389.

Caulford, P. \& Vali, Y. (2006). Providing health care to medically uninsured immigrants and refugees. Canadian Medical Association Journal, 174(9), 1253-1254.

Chabot, I., Goetghebeur, M., \& Grégoire, J-P. (2004). The societal value of universal childhood vaccination. Vaccine, 22(15-16), 1992-2005.

Child Health Alert Newsletter. (2010). Immunize Children Against the Flu, And The Adult Community Also Benefits. Child Health Alert, 28(1), 2-3.

Citizenship and Immigration Canada [CIC]. (2011). Visiting Canada. Retrieved May 
15, 2011 from http://www.cic.gc.ca.english/visit/index.asp

Department of Justice Canada [DJC]. (1982). Canadian Charter of Rights and

Freedoms. Retrieved May 10, 2011 from

http://laws-lois.justice.gc.ca/eng/charter/

Department of Justice Canada [DJC]. (1985). Canada Health Act.

Retrieved May 10, 2011 from

http://laws-lois.justice.gc.ca/eng/acts/C-6/page-2.html

Ford-Jones, E., Williams, R., \& Bertrand, J. (2008). Social paediatrics and early

childhood development: Part 1. Paediatric Child Health, 13(9), 755-758.

Freeman, M. (2007). Why it Remains Important to Take Children's Rights Seriously. International Journal of Children's Rights, 15(1), 5-23.

Goldman, N., \& Pebley, A. (1994). Childhood immunization and pregnancy-related services in Guatemala. Health Transition Review, 4(1), 29-43.

Goldring, L., Berinstein, C., \& Bernhard, J.K. (2009). Institutionalizing precarious migratory status in Canada. Citizenship Stúdies, 13(3), 237-263.

Gortmaker, S. (1979). The effects of prenatal care upon the health of the newborn. American Journal of Public Health, 69(7), 653-660.

Gravetter, F. \& Wallnau, L. (2007). Statistics for the Behavioral Sciences. (7th ed). Belmont, CA: Thomson Wadsworth

Guyda, H., Razack, S., \& Steinmetz, N. (2006). Social paediatrics. Paediatric Child Health, 11(10), 643-645.

Health Canada. (2009). Canada's Health Care System. Retrieved May 20, 2011 from http://www.hc-sc.gc.ca/hcs-sss/index-eng.php 
Iglehart, J.K. (1986). Canada's Health Care System. New England Journal of Medicine, $315(1), 202-208$.

Kielhofner, G. (2006). Research in Occupational Therapy: Methods of Inquiry for Enhancing Practice. Philadelphia, PA: F.A. Davis Company.

Kurtz, Z. (1994). Children's Rights and Health Care. Children \& Society, 8(2), 114-131.

Lansdown, G. (2000). Implementing children's rights and health. Archives of Disease in Childhood, 83(4), 286-288.

Newbold, K., \& Danforth, J. (2003). Health status and Canada's immigrant population. Social Science \& Medicine, 57(10), 1981-1995.

Nugent, Z. (2009). [Children without medical insurance in a Canadian metropolitan city]. Unpublished raw data.

Nugent, Z., Chan, K., Hilliard, R.L., Ford-Jones, E.L., Caulford, P. (2011). Children without medical insurance in a Canadian metropolitan city. Paediatric and Child Health, 16(Suppl A), 42A.

Ontario Medical Review, OMA Policy Paper. (2011). Reviewing the OHIP ThreeMonth Wait: unreasonable barrier to accessing health care. Retrieved June 5, 2011 from https://www.oma,org/Resources/Documents/Apr11_OHIP_feature_pp1318.pdf

Ontario Ministry of Health and Long-Term Care [OMHLC]. (2008). Retrieved May 29, 2011 from http://www.health.gov.on.ca/en/public/programs/ohip

Raman, S., Woolfenden, S., Williams, K., \& Zwi, K. (2007). Human rights and child health. Journal of Paediatrics and Child Health, 43(7), 581-586. 
Ramey, C., \& Landesman Ramey, S. (1998). Early intervention and early experience. American Psychologist, 53(2), 109-120.

Roos, L., Traverse, D., \& Turner, D. (1999). Delivering prevention: the role of public programs in delivering care to high-risk populations. [Supplemental material]. Medical Care, 37(6 Suppl): JS264-78.

Ruiz-Casares, M. (2010). Right and access to healthcare for undocumented children: Addressing the gap between international conventions and disparate implementations in North America and Europe. Social Science \& Medicine, $70(1), 329-336$.

Sigona, N. (2011). Policy Primer: Irregular Migrant Children and Public Policy. The Migration Observatory. Retrieved March 10, 2011 from www.migrationobservatory.ox.ac.uk

Simich, L., Wu, F., \& Nerad, S. (2007). Status and Health Security: An Exploratory Study of Irregular Immigrants in Toronto. Canadian Journal of Public Health, 98(5), 369-373.

Snow, K. (2009). Vulnerable citizens: The oppression of children in care. Journal of Child and Youth Care Work, 21, 94-113.

United Nations Convention on the Rights of the Child [UNCRC]. (1989/1991). Ottawa, Ontario: Government of Canada, Multiculturalism \& Citizenship Canada.

United Nations High Commissioner for Refugees [UNHCR]. (1951). Retrieved May 5, 2011 from http://www.unhcr.org/4ca34be29.html 
Waterston, T., \& Goldhagen, J. (2006). Why children's rights are central to international child health. Archives of Disease in Childhood, 92(2), 176-180.

Webb, E., Horrocks, L., Crowley, A., \& Lessof, N. (2009). Using the UN Convention on the Rights of Children to improve the health of children. Paediatrics and Child Health, 19(9), 430-434.

Weissman, J., Stern, R., Fielding, S., \& Epstein, A. (1991). Delayed Access to Health Care: Risk Factors, Reasons, and Consequences. Medicine and Public Issues, $114(4), 325-331$.

World Health Organization (WHO). (2010). Report on the Equity, social determinants and public health programmes. Retrieved January 6, 2011 from http://www.who.int/social_determinants/en/ 